\title{
FINANCIAL INTEGRATION IN ASSET AND LIABILITY HOLDINGS IN EAST ASIA
}

Donghyun Park and Kwanho Shin

NO. 444

August 2015
ADB ECONOMICS WORKING PAPER SERIES 
ADB Economics Working Paper Series

\section{Financial Integration in Asset and Liability Holdings in East Asia}

Donghyun Park and Kwanho Shin

No. 444 | August 2015
Donghyun Park (dpark@adb.org) is Principal Economist at the Economic Research and Regional Cooperation Department, Asian Development Bank. Kwanho Shin (khshin@korea.ac.kr) is Professor at the Department of Economics, Korea University.

This paper was prepared as a background paper for the Asian Development Outlook 2015. We thank Dongho Choo for excellent research assistance. We also thank the Bank for International Settlements for providing bilateral bank lending statistics. This work was also supported by the National Research Foundation of Korea Grant funded by the Korean Government (NRF2014S1A5A2A03065052). 
Asian Development Bank

6 ADB Avenue, Mandaluyong City

1550 Metro Manila, Philippines

www.adb.org

(C) 2015 by Asian Development Bank

August 2015

ISSN 2313-6537 (Print), 2313-6545 (e-ISSN)

Publication Stock No. WPS157567-2

The views expressed in this paper are those of the authors and do not necessarily reflect the views and policies of the Asian Development Bank (ADB) or its Board of Governors or the governments they represent.

ADB does not guarantee the accuracy of the data included in this publication and accepts no responsibility for any consequence of their use.

By making any designation of or reference to a particular territory or geographic area, or by using the term "country" in this document, $A D B$ does not intend to make any judgments as to the legal or other status of any territory or area.

Notes:

1. In this publication, "\$” refers to US dollars.

2. ADB recognizes "China" as the People's Republic of China and "Korea" as the Republic of Korea.

The ADB Economics Working Paper Series is a forum for stimulating discussion and eliciting feedback on ongoing and recently completed research and policy studies undertaken by the Asian Development Bank (ADB) staff, consultants, or resource persons. The series deals with key economic and development problems, particularly those facing the Asia and Pacific region; as well as conceptual, analytical, or methodological issues relating to project/program economic analysis, and statistical data and measurement. The series aims to enhance the knowledge on Asia's development and policy challenges; strengthen analytical rigor and quality of ADB's country partnership strategies, and its subregional and country operations; and improve the quality and availability of statistical data and development indicators for monitoring development effectiveness.

The ADB Economics Working Paper Series is a quick-disseminating, informal publication whose titles could subsequently be revised for publication as articles in professional journals or chapters in books. The series is maintained by the Economic Research and Regional Cooperation Department. 


\section{CONTENTS}

TABLES AND FIGURES $\quad$ iv

ABSTRACT V v

$\begin{array}{ll}\text { I. INTRODUCTION } & 1\end{array}$

II. REGIONAL FINANCIAL INTEGRATION: ASIA VERSUS EUROPE 2

III. A GRAVITY MODEL APPROACH TO MEASURING REGIONAL

IV. REGIONAL FINANCIAL COOPERATION AND DIVERSIFICATION
OF FUNDING SOURCES

V. CONCLUSIONS

$\begin{array}{ll}\text { APPENDIX } & 37\end{array}$

$\begin{array}{ll}\text { REFERENCES } & 39\end{array}$ 


\section{TABLES AND FIGURES}

\section{TABLES}

1. Geographical Distribution of Portfolio Investment, 2001-2013 Averages 5

1.a Total Portfolio

1.b Equity Securities 6

1.c Long-Term Debt Securities $\quad 7$

1.d Short-Term Debt Securities 8

2 Summary Statistics, 2001-2012 20

3 Portfolio Estimation with Regional and Global Dummies $\quad 22$

3.a Total Portfolio $\quad 22$

3.b Equity Securities 23

3.c Long-Term Debt Securities 24

3.d Short-Term Debt Securities $\quad 25$

4 Diversity of Portfolio Liabilities and Factors Associated with Exchange Rate

5 Diversity of Bank Lending Liabilities and Factors Associated with Exchange Rate

Depreciation, April-August 2013

\section{FIGURES}

1 Geographical Distribution of Portfolio Asset Holdings from 2001 to 2013,

East Asia versus Europe

1.a Total Portfolio 9

$\begin{array}{ll}\text { 1.b Equity Securities } & 10\end{array}$

1.c Long-Term Debt Securities 11

1.d Short-Term Debt Securities $\quad 12$

2 Geographical Distribution of Portfolio Liabilities from 2001 to 2013,

East Asia versus Europe $\quad 14$

2.a Total Portfolio $\quad 14$

2.b Equity Securities $\quad 15$

2.c Long-Term Debt Securities 16

2.d Short-Term Debt Securities $\quad 17$

3 Diversity of Liabilities and Exchange Rate Depreciation, $2012 \quad 32$

3.a Total Portfolio $\quad 32$

$\begin{array}{lll}\text { 3.b Equity Securities } & 32\end{array}$

3.c Long-Term Debt Securities 33

3.d Short-Term Debt Securities 33

3.e Bank Lending $\quad 34$ 


\begin{abstract}
In this paper, we examine the evolution of intra-East Asian financial integration from 2001 to 2013. Most existing studies on this topic look primarily at asset holdings; we examine liability holdings as well. Using the International Monetary Fund's Coordinated Portfolio Investment Survey data for equities, long-term debt, and short-term debt, our analysis generally supports the conventional wisdom that East Asian countries are more financially integrated with global financial centers than they are with each other. This is true for both asset holdings and liabilities and is confirmed by an econometric analysis based on financial gravity equations. However, the gap between global integration and regional integration has narrowed for asset holdings over time but not for liability holdings. The results of additional econometric analysis indicate that the diversification of liability holdings can mitigate financial instability due to global financial shocks. More precisely, diversification was associated with smaller exchange rate depreciation during the quantitative easing taper tantrum of 2013. These results point to a possible benefit from strengthening regional financial integration. Deeper regional integration would reduce dependence on global financial markets for funding and hence vulnerability to global shocks.
\end{abstract}

Keywords: East Asia, exchange rate depreciation, financial integration, financial stability, global integration, QE tapering, regional integration

JEL Classification: F32, F44, G01 


\section{INTRODUCTION}

International capital mobility is rapidly increasing in East Asia; however, several studies point out that economies in East Asia are financially more integrated with global financial markets than they are with each other. For example, Kim, Lee, and Shin (2008), using a gravity model of bilateral financial asset holdings, found that East Asian financial markets were relatively less integrated with each other than with global markets, particularly compared with European ones. Based on both quantity- and pricebased measures of financial integration, Lee and Park (2011) also found that Asia's equity markets were more integrated globally than regionally.

In this paper, we analyze whether this tendency toward global financial integration has persisted in East Asia. Since regional financial integration in other areas, for example Europe, is much deeper, one might expect this bias toward global integration in East Asia to weaken over time, all the more so since policy makers are making a concerted effort to increase financial cooperation among the Association of Southeast Asian Nations (ASEAN) +3 members. An innovation in our paper is that while most previous studies on financial integration looked exclusively at asset holdings, we consider financial integration in liability holdings as well.

Using Coordinated Portfolio Investment Survey (CPIS) data for equities, long-term debt, and short-term debt, our analysis generally supports the conventional wisdom that East Asian countries are more financially integrated with global financial centers than with each other. This is true for both asset holdings and liabilities and is confirmed by an econometric analysis based on financial gravity equations. However, the gap between global integration and regional integration has narrowed over time for asset holdings but not for liability holdings.

The literature sets forth a number of well-known potential benefits for financial integration in general. These include (i) faster growth due to faster capital accumulation if capital moves from richer countries to poorer countries, ${ }^{1}$ (ii) faster growth due to technology spillover particularly through foreign direct investment (FDI), ${ }^{2}$ (iii) consumption smoothing via lending and borrowing, (iv) risk sharing via diversification of investment risks, and (v) collateral benefits. ${ }^{3}$

In contrast to financial integration in general, however, there is relatively little theoretical justification for regional financial integration. ${ }^{4}$ One argument is that more regional financial integration can foster the formation of a regional monetary union by reducing the costs of joining one; however, the euro crisis clearly shows that forming a monetary union without fiscal integration is suboptimal. Given the even more heterogeneous national income levels across East Asia, it will be even more difficult to form a monetary union without fiscal integration.

Another justification for regional financial integration is that it can strengthen regional financial cooperation. Since the Asian financial crisis of 1997 and 1998, East Asian policy makers have called for

Lucas (1990) found that international capital tends to move in the opposite direction, a phenomenon called the "Lucas paradox."

2 Gourinchas and Jeanne (2006) argued that the growth effect coming from technological spillover is much more important than the growth effect coming from faster capital accumulation. Lee and Shin (2012) also confirmed the importance of technological spillovers.

3 Kose et al. (2009) argued that these benefits include development of the domestic finance sector, discipline on macroeconomic policies, efficiency gains among domestic firms associated with exposure to competition from foreign entrants, and unleashing forces that result in better government and corporate governance.

4 See for example Kim, Lee, and Shin (2008). 
closer regional financial cooperation, partly in response to widespread perceptions that the International Monetary Fund (IMF) failed to deal effectively with that crisis. The Chiang Mai Initiative and its multilateralization is the most concrete example of such efforts, but there is a long way to go to build an Asian institution that could replace the IMF.

In this paper, we propose an alternative, indirect justification for regional financial integration-reduction of exposure to external shocks. To test our proposal, we empirically assess whether diversification of funding sources can reduce vulnerability to global financial shocks. The underlying premise is that East Asia's heavy dependence on financially advanced economies, i.e., the United States (US) and Europe, as sources of funding leaves it dangerously exposed to financial shocks originating from those economies. Hence regional financial integration can dilute the impact of external shocks by reducing East Asia's financial dependence on countries outside the region. This consideration is especially relevant since the global financial crisis and the erosion of the traditional role of the advanced economies as anchors of global stability. The unorthodox monetary policies of those economies, i.e. quantitative easing (QE), and their unwinding can also have a destabilizing effect on East Asian financial markets as was evident during the QE taper tantrum of 2013.

Our econometric analysis indicates that diversification of liability holdings can mitigate financial instability due to global financial shocks. More precisely, diversification was associated with smaller exchange rate depreciation during the taper tantrum. These results point to a possible benefit from strengthening regional financial integration as it would reduce dependence on global financial markets for funding and hence vulnerability to global shocks.

In Section II we analyze the geographical distribution of international portfolio assets and liabilities for East Asia. In Section III we test a gravity model of bilateral financial asset holdings to formally investigate the degree to which East Asian financial markets are integrated with each other rather than with global markets. In both Sections III and IV, we also look at Europe for comparative purposes. Section IV empirically analyzes whether geographical diversification of liabilities, i.e. funding sources, mitigates financial shocks originating from advanced countries. Section $\vee$ concludes the paper.

\section{REGIONAL FINANCIAL INTEGRATION: ASIA VERSUS EUROPE}

Several studies in the literature estimate the degree of regional and global financial integration. In general, we can classify these studies into two strands. The first is based on direct measures of bilateral capital flows. This approach assumes that the degree of financial integration between two countries is higher if they trade more financial assets. The second strand is to use an indirect measure based on the returns to financial assets. ${ }^{5}$ For example, if the interest rates move very closely in two countries, the studies conclude that their bond markets are closely integrated.

With respect to the second strand, a general note of caution is warranted in inferring the extent of financial integration from comovements of returns to financial assets. For example, if two markets are deeply integrated with a common global market such as the US market despite little actual integration with each other, then their interest rates can move closely together. Since we plan to examine and compare regional versus global integration, the second approach could be seriously flawed.

5 See, for example, Sohn and Shin (2006) and other papers cited therein. 
Therefore, we rely on the first approach and examine the stylized pattern of the regional and global composition of the portfolio asset and liability holdings of East Asian and European countries. We include European countries for comparative purposes. Bilateral data on international asset holdings are rare; we used the IMF's CPIS data available annually from 2001 to 2013. The data are constructed on the basis of a voluntary survey of 67 source economies, including several offshore and financial centers. ${ }^{6}$ For each economy, the bilateral asset holding positions of the source economies in 223 destination countries and territories are reported. The assets are classified into three types of portfolio investments: equities, long-term debt securities, and short-term debt securities.

The CPIS data include eight East Asian economies as sources: Hong Kong, China; Indonesia; Japan; Republic of Korea; Malaysia; Philippines; Singapore; and Thailand. The People's Republic of China (PRC) is included only as a destination economy. Thus in our analysis, when we examine asset holdings, the PRC is excluded, but it is included when we look at liability holdings. We also consider 17 European economies as both sources and hosts including three outside the eurozone. Definitions of all the variables used in the empirical analysis of this paper and their data sources are in Appendix Table A.1.

Table 1 reports the geographical distribution of portfolio asset holdings for the 8 East Asian and 17 European economies. Table 1.a reports each country's share of total portfolio investments-the sum of equity, long-term debt, and short-term debt-in three regions: East Asia, Europe (and the United Kingdom [UK] separately), and the US. We calculated the average shares from 2001 to 2013. The table clearly shows that the intraregional share was much smaller in East Asia than it was in Europe. On average, the intra-East Asian share of total East Asian portfolio investments was $21.4 \%$ while the intraEuropean share for European countries was $55.7 \%$. In particular, Japan and the Philippines had the lowest regional shares at $1.9 \%$ and $17 \%$, respectively.

In contrast, the share of the global market, i.e. the US (27.1\%), in East Asian total portfolio investment was much greater than that of European countries (15.4\%). Even if we include the UK as a global market, the share of global markets was higher for East Asia than for Europe at 35.3\% versus 24.8\%. In the last row, we also report the total portfolio asset holdings of the US. It invested much more in Europe (55.7\%) than in East Asia (13.2\%).

In the last two columns, we report the size of total portfolio investments in 2013. On average, individual European economies invested $\$ 1,114.3$ billion while individual East Asian economies invested $\$ 645.6$ billion. As a percent of gross domestic product (GDP), East Asian economies invested 87.7\% and European economies invested $157.8 \%$. The figure is particularly large for Hong Kong, China (352.7\%) and for Singapore (242.8\%), two major financial centers.

Table 1.b reports each country's average purchases of equity securities in the three regions from 2001 to 2013. Overall we observe a similar picture. The intraregional share of East Asian equity investments is $24.7 \%$ which is much lower than the intraregional share for Europe at $41.3 \%$. The share of global markets in East Asian equity investments is $27.1 \%$ (excluding the UK) and $33.4 \%$ (including the UK) which is higher than the figures for Europe at $18.6 \%$ and $27.7 \%$, respectively.

6 Lane and Milesi-Ferretti (2003) pointed out that CPIS data are subject to shortcomings due to problems of survey methods and the under-reporting of assets by participating countries. 
The relatively low intraregional share for East Asia is even more pronounced in the holdings of long-term debt securities reported in Table 1.c. The average East Asian intraregional share is 17.2\% which is much smaller than the intra-European share at 66.5\%. The gap in the share of the global markets in long-term debt securities between East Asia and Europe is larger than that in equity at 28.3\% (36.1\% if the UK is included) in East Asia versus 13.1\% (22\% if the UK is included) in Europe. Note that CPIS data do not cover international reserve holdings by monetary authorities. Since the amount of the US Treasury bonds held as international reserves in East Asia is enormous, if they are included, the tendency to rely on global markets in East Asia is even greater.

Finally, Table 1.d shows that a similar pattern is observed in holdings of short-term debt securities. The average East Asian intraregional share is $21.6 \%$ while the average intraregional share in Europe is $68.8 \%$. In contrast, the average share of global markets in East Asian holdings of short-term debt securities is $32.9 \%$ (47.4\% if the UK is included) which is much larger than that of European countries at $12.3 \%$ (24.2\% if the UK is included). Again, if international reserve holdings are included, the gap between East Asia and Europe is even wider.

So far we have examined investment patterns from 2001 to 2013 based on average shares without considering changing patterns over time. Figure 1 illustrates how the shares of intraregional and global holdings of portfolio investments evolved from 2001 to 2013. Figure 1.a, which is based on holdings of total portfolio investments, shows that the intraregional share has been increasing and the share of global markets decreasing, with the former surpassing the latter in 2007; however, the gap between the two shares had not widened since 2007, and the two were more or less converging at around 25\%. In contrast, for Europe, the intraregional share and share of global markets in total portfolio investments did not change much since 2001 with the former at around $60 \%$ and the latter at around $10 \%$.

In Figure 1.b we illustrate the shares of intraregional and global markets in East Asian holdings of equity securities. They are more volatile and do not show any visible trends. Furthermore, both shares take more or less the same value. In Europe, however, while both shares are slightly declining, the intraregional share is much greater than the share of global markets over the entire period.

In Figure 1.c the shares of intraregional and global holdings of long-term debt securities show a very similar pattern to that of total portfolio investment in Figure 1a. The intraregional share rises while the share of global markets falls in East Asia. The intraregional share began to exceed the global share in 2010. In Europe, however, there is no visible trend in either intraregional or global shares; the former is always much greater than the latter.

Finally Figure 1.d illustrates the pattern of intraregional and global shares in holdings of shortterm debt securities. The overall pattern is similar to the one for long-term debt securities, but the shares are much more volatile. Both shares are, however, converging over time. In Europe, the shares are again more volatile, but there is no visible trend, and the intraregional share is always much greater than the global share. 
Table 1: Geographical Distribution of Portfolio Investment, 2001-2013 Averages

Table 1.a: Total Portfolio

\begin{tabular}{|c|c|c|c|c|c|c|}
\hline \multirow[b]{2}{*}{ Source } & \multicolumn{4}{|c|}{$\begin{array}{c}\text { Percent of Portfolio Assets Held in Each } \\
\text { Region/Economy }\end{array}$} & \multicolumn{2}{|c|}{ Total (2013) } \\
\hline & East Asia & Europe & (UK) & US & ( $\$$ billion) & $(\%$ of GDP) \\
\hline Hong Kong, China & 25.2 & 20.4 & 11.7 & 11.9 & 966.3 & 352.7 \\
\hline Indonesia & 17.2 & 24.5 & 7.7 & 15.6 & 14.2 & 1.6 \\
\hline Japan & 1.9 & 33.1 & 6.4 & 34.2 & $3,224.8$ & 65.8 \\
\hline Republic of Korea & 17.4 & 17.6 & 6.6 & 38.5 & 146.9 & 11.3 \\
\hline Malaysia & 38.7 & 17.7 & 8.2 & 18.6 & 55.0 & 17.6 \\
\hline Philippines & 17.0 & 16.3 & 8.2 & 50.0 & 5.9 & 2.2 \\
\hline Singapore & 24.3 & 22.3 & 12.0 & 23.9 & 723.4 & 242.8 \\
\hline Thailand & 29.3 & 17.9 & 5.1 & 23.8 & 28.2 & 7.3 \\
\hline East Asia, average & 21.4 & 21.2 & 8.2 & 27.1 & 645.6 & 87.7 \\
\hline Austria & 1.3 & 66.9 & 5.7 & 8.6 & 333.1 & 80.1 \\
\hline Belgium & 0.8 & 66.5 & 4.6 & 7.2 & 657.4 & 129.4 \\
\hline Denmark & 5.4 & 56.9 & 8.2 & 21.7 & 361.1 & 109.2 \\
\hline Finland & 1.6 & 73.8 & 7.8 & 8.4 & 327.1 & 127.4 \\
\hline France & 4.5 & 69.6 & 9.1 & 9.9 & $2,583.8$ & 94.5 \\
\hline Germany & 2.0 & 63.6 & 7.7 & 9.6 & $2,801.3$ & 77.1 \\
\hline Greece & 0.1 & 48.7 & 28.1 & 8.3 & 141.5 & 58.6 \\
\hline Iceland & 2.2 & 45.2 & 12.5 & 23.8 & 9.0 & 61.5 \\
\hline Ireland & 4.7 & 53.6 & 18.9 & 27.7 & $2,153.5$ & 988.8 \\
\hline Italy & 1.4 & 49.8 & 5.6 & 10.1 & $1,045.1$ & 50.5 \\
\hline Netherlands & 4.4 & 58.0 & 8.9 & 24.2 & $1,652.6$ & 206.5 \\
\hline Norway & 7.9 & 56.1 & 11.1 & 23.4 & $897.0^{*}$ & $179.4^{*}$ \\
\hline Portugal & 0.3 & 69.5 & 6.8 & 6.0 & 143.2 & 65.1 \\
\hline Spain & 0.8 & 68.1 & 8.5 & 7.9 & $420.6^{*}$ & $31.8^{*}$ \\
\hline Sweden & 4.9 & 48.8 & 11.4 & 25.4 & $505.4^{*}$ & $96.5^{*}$ \\
\hline Switzerland & 2.8 & 41.9 & 5.7 & 14.3 & $1,152.6$ & 177.1 \\
\hline United Kingdom & 10.3 & 39.2 & 0.0 & 25.8 & $3,758.3$ & 149.0 \\
\hline Europe, average & 3.3 & 57.4 & 9.4 & 15.4 & $1,114.3$ & 157.8 \\
\hline United States & 13.2 & 55.7 & 22.3 & 0.0 & $8,282.8$ & 49.3 \\
\hline
\end{tabular}


6 ADB Economics Working Paper Series No. 444

Table 1 continued

Table 1.b: Equity Securities

\begin{tabular}{|c|c|c|c|c|c|c|}
\hline \multirow[b]{2}{*}{ Source } & \multicolumn{4}{|c|}{$\begin{array}{l}\text { \% of Portfolio Assets Held in Each } \\
\text { Region/Economy }\end{array}$} & \multicolumn{2}{|c|}{ Total (2013) } \\
\hline & East Asia & Europe & (UK) & US & ( $\$$ billion) & (\% of GDP) \\
\hline Hong Kong, China & 25.5 & 17.4 & 14.7 & 4.9 & 581.9 & 212.4 \\
\hline Indonesia & 28.2 & 12.9 & 0.1 & 20.9 & 2.3 & 0.3 \\
\hline Japan & 5.5 & 27.4 & 9.5 & 45.0 & 672.4 & 13.7 \\
\hline Republic of Korea & 23.2 & 11.6 & 5.1 & 27.2 & 104.0 & 8.0 \\
\hline Malaysia & 49.8 & 7.9 & 4.9 & 18.5 & 35.1 & 11.2 \\
\hline Philippines & 9.7 & 18.9 & 5.9 & 57.5 & 0.1 & 0.0 \\
\hline Singapore & 33.6 & 13.8 & 7.6 & 26.2 & 412.1 & 138.3 \\
\hline Thailand & 21.9 & 16.4 & 2.3 & 16.7 & 7.5 & 1.9 \\
\hline East Asia, average & 24.7 & 15.8 & 6.3 & 27.1 & 226.9 & 48.2 \\
\hline Austria & 3.5 & 48.1 & 6.1 & 12.7 & 89.2 & 21.5 \\
\hline Belgium & 1.6 & 38.8 & 4.2 & 7.2 & 237.4 & 46.7 \\
\hline Denmark & 10.1 & 43.1 & 11.6 & 28.5 & 170.9 & 51.7 \\
\hline Finland & 3.7 & 53.6 & 10.9 & 13.7 & 154.9 & 60.3 \\
\hline France & 6.9 & 53.1 & 10.1 & 12.8 & 650.2 & 23.8 \\
\hline Germany & 3.3 & 38.1 & 6.8 & 11.2 & 793.7 & 21.8 \\
\hline Greece & 0.6 & 24.6 & 11.3 & 20.0 & 6.1 & 2.5 \\
\hline Iceland & 2.7 & 42.7 & 11.7 & 23.0 & 5.1 & 34.8 \\
\hline Ireland & 10.1 & 45.1 & 17.9 & 26.5 & 704.2 & 323.3 \\
\hline Italy & 2.7 & 30.1 & 3.5 & 7.2 & 518.1 & 25.0 \\
\hline Netherlands & 8.8 & 35.7 & 11.7 & 37.2 & 735.1 & 91.9 \\
\hline Norway & 9.9 & 47.2 & 14.2 & 27.8 & $502.2^{*}$ & $100.4^{*}$ \\
\hline Portugal & 1.1 & 48.9 & 7.8 & 9.7 & 30.5 & 13.9 \\
\hline Spain & 2.6 & 51.4 & 9.1 & 9.4 & $118.3^{*}$ & $8.9^{*}$ \\
\hline Sweden & 6.5 & 39.0 & 11.4 & 26.8 & $355.5^{*}$ & $67.8^{*}$ \\
\hline Switzerland & 4.5 & 27.7 & 5.6 & 16.7 & 498.3 & 76.6 \\
\hline United Kingdom & 17.9 & 34.4 & 0.0 & 26.2 & $1,324.2$ & 52.5 \\
\hline Europe, average & 5.7 & 41.3 & 9.1 & 18.6 & 405.5 & 60.2 \\
\hline United States & 19.1 & 47.4 & 16.2 & 0.0 & $5,632.1$ & 33.5 \\
\hline
\end{tabular}


Table 1.c: Long-Term Debt Securities

\begin{tabular}{|c|c|c|c|c|c|c|}
\hline \multirow[b]{2}{*}{ Source } & \multicolumn{4}{|c|}{$\begin{array}{l}\% \text { of Portfolio Assets Held in Each } \\
\text { Region/Economy }\end{array}$} & \multicolumn{2}{|c|}{ Total (2013) } \\
\hline & East Asia & Europe & (UK) & US & ( $\$$ billion) & (\% of GDP) \\
\hline Hong Kong, China & 16.8 & 26.2 & 9.3 & 24.8 & 209.6 & 76.5 \\
\hline Indonesia & 13.3 & 29.7 & 7.9 & 14.7 & 9.2 & 1.1 \\
\hline Japan & 1.0 & 34.5 & 5.6 & 31.7 & $2,528.2$ & 51.6 \\
\hline Republic of Korea & 8.9 & 24.3 & 7.9 & 46.2 & 42.2 & 3.2 \\
\hline Malaysia & 29.9 & 25.4 & 9.3 & 15.9 & 19.1 & 6.1 \\
\hline Philippines & 17.5 & 12.8 & 7.6 & 43.5 & 4.6 & 1.7 \\
\hline Singapore & 19.4 & 27.5 & 7.3 & 25.2 & 289.4 & 97.1 \\
\hline Thailand & 31.0 & 21.4 & 7.4 & 24.5 & 10.7 & 2.8 \\
\hline East Asia, average & 17.2 & 25.2 & 7.8 & 28.3 & 389.1 & 30.0 \\
\hline Austria & 0.6 & 72.5 & 5.5 & 7.4 & 239.7 & 57.7 \\
\hline Belgium & 0.3 & 80.8 & 4.8 & 7.0 & 402.2 & 79.2 \\
\hline Denmark & 1.7 & 67.6 & 5.5 & 16.1 & 184.3 & 55.7 \\
\hline Finland & 0.2 & 87.8 & 6.0 & 4.9 & 168.1 & 65.5 \\
\hline France & 1.8 & 75.6 & 7.8 & 9.2 & $1,646.8$ & 60.2 \\
\hline Germany & 1.3 & 75.9 & 7.9 & 8.4 & $1,971.5$ & 54.2 \\
\hline Greece & 0.1 & 51.9 & 29.6 & 6.8 & 131.4 & 54.4 \\
\hline Iceland & 0.4 & 57.2 & 13.4 & 17.2 & 0.2 & 1.3 \\
\hline Ireland & 1.4 & 59.2 & 16.5 & 23.6 & $1,065.3$ & 489.1 \\
\hline Italy & 0.5 & 63.8 & 7.0 & 12.1 & 516.7 & 25.0 \\
\hline Netherlands & 1.1 & 73.9 & 6.7 & 15.1 & 881.4 & 110.2 \\
\hline Norway & 6.3 & 63.7 & 8.8 & 19.9 & $393.1^{*}$ & $78.6^{*}$ \\
\hline Portugal & 0.1 & 74.0 & 6.7 & 5.5 & 104.7 & 47.6 \\
\hline Spain & 0.1 & 72.6 & 8.4 & 7.5 & $284.8^{*}$ & $21.5^{*}$ \\
\hline Sweden & 1.9 & 67.6 & 11.4 & 23.1 & $144.6^{*}$ & $27.6^{*}$ \\
\hline Switzerland & 1.5 & 45.3 & 5.2 & 13.2 & 593.8 & 91.2 \\
\hline United Kingdom & 5.2 & 40.6 & 0.0 & 26.1 & $2,324.8$ & 92.2 \\
\hline Europe, average & 1.4 & 66.5 & 8.9 & 13.1 & 650.2 & 83.0 \\
\hline United States & 6.0 & 41.5 & 15.8 & 0.0 & $2,258.4$ & 13.4 \\
\hline
\end{tabular}


Table 1 continued

Table 1.d: Short-Term Debt Securities

\begin{tabular}{|c|c|c|c|c|c|c|}
\hline \multirow[b]{2}{*}{ Source } & \multicolumn{4}{|c|}{$\begin{array}{l}\% \text { of Portfolio Assets Held in Each } \\
\text { Region/Economy }\end{array}$} & \multicolumn{2}{|c|}{ Total (2013) } \\
\hline & East Asia & Europe & (UK) & US & (\$ billion) & ( $\%$ of GDP) \\
\hline Hong Kong, China & 43.6 & 19.1 & 6.9 & 9.2 & 174.8 & 63.8 \\
\hline Indonesia & 27.0 & 17.2 & 11.7 & 29.0 & 2.8 & 0.3 \\
\hline Japan & 2.5 & 33.8 & 12.7 & 33.5 & 24.2 & 0.5 \\
\hline Republic of Korea & 9.7 & 21.7 & 16.8 & 58.7 & 0.6 & 0.1 \\
\hline Malaysia & 25.1 & 37.6 & 12.6 & 29.6 & 0.8 & 0.3 \\
\hline Philippines & 9.8 & 9.9 & 4.4 & 71.2 & 1.2 & 0.5 \\
\hline Singapore & 20.8 & 56.7 & 47.3 & 7.9 & 96.7 & 32.5 \\
\hline Thailand & 34.4 & 12.6 & 3.9 & 23.7 & 9.9 & 2.6 \\
\hline East Asia, average & 21.6 & 26.1 & 14.5 & 32.9 & 38.9 & 12.6 \\
\hline Austria & 0.2 & 67.2 & 7.6 & 8.0 & 4.2 & 1.0 \\
\hline Belgium & 0.1 & 73.6 & 6.1 & 10.0 & 17.8 & 3.5 \\
\hline Denmark & 0.4 & 66.5 & 6.5 & 18.0 & 6.0 & 1.8 \\
\hline Finland & 0.0 & 93.1 & 4.9 & 1.8 & 4.1 & 1.6 \\
\hline France & 16.1 & 69.4 & 16.5 & 7.6 & 286.8 & 10.5 \\
\hline Germany & 4.1 & 66.4 & 5.5 & 14.7 & 36.0 & 1.0 \\
\hline Greece & 0.0 & 66.4 & 52.0 & 3.4 & 4.0 & 1.7 \\
\hline Iceland & 3.4 & 56.1 & 23.1 & 30.9 & 3.7 & 25.4 \\
\hline Ireland & 1.1 & 51.3 & 25.3 & 37.2 & 384.1 & 176.4 \\
\hline Italy & 0.2 & 80.5 & 11.9 & 4.7 & 10.2 & 0.5 \\
\hline Netherlands & 3.7 & 72.5 & 9.8 & 11.7 & 36.1 & 4.5 \\
\hline Norway & 0.8 & 73.8 & 2.6 & 20.9 & $1.7^{*}$ & $0.3^{*}$ \\
\hline Portugal & 0.0 & 78.4 & 6.8 & 2.0 & 8.1 & 3.7 \\
\hline Spain & 0.0 & 70.1 & 4.3 & 3.3 & $17.5^{*}$ & $1.3^{*}$ \\
\hline Sweden & 1.4 & 73.8 & 8.7 & 13.9 & $5.8^{*}$ & $1.0^{*}$ \\
\hline Switzerland & 0.9 & 59.5 & 10.2 & 6.2 & 60.5 & 9.3 \\
\hline United Kingdom & 8.2 & 51.6 & 0.0 & 15.5 & 109.3 & 4.3 \\
\hline Europe, average & 2.4 & 68.8 & 11.9 & 12.3 & 58.6 & 14.6 \\
\hline United States & 4.8 & 67.8 & 38.1 & 0.0 & 392.3 & 2.3 \\
\hline
\end{tabular}

GDP = gross domestic product, UK = United Kingdom, US = United States.

Note: East Asia refers to nine economies including the People's Republic of China (PRC). The PRC is included only as a host country. Values with * are for those countries with missing values in 2013 and values for 2012 are reported. Total portfolio investments consist of equity, longterm debt, and short-term debt securities.

Source: Authors' calculations based on International Monetary Fund, the Coordinated Portfolio Investment Survey, 2001-2013. 


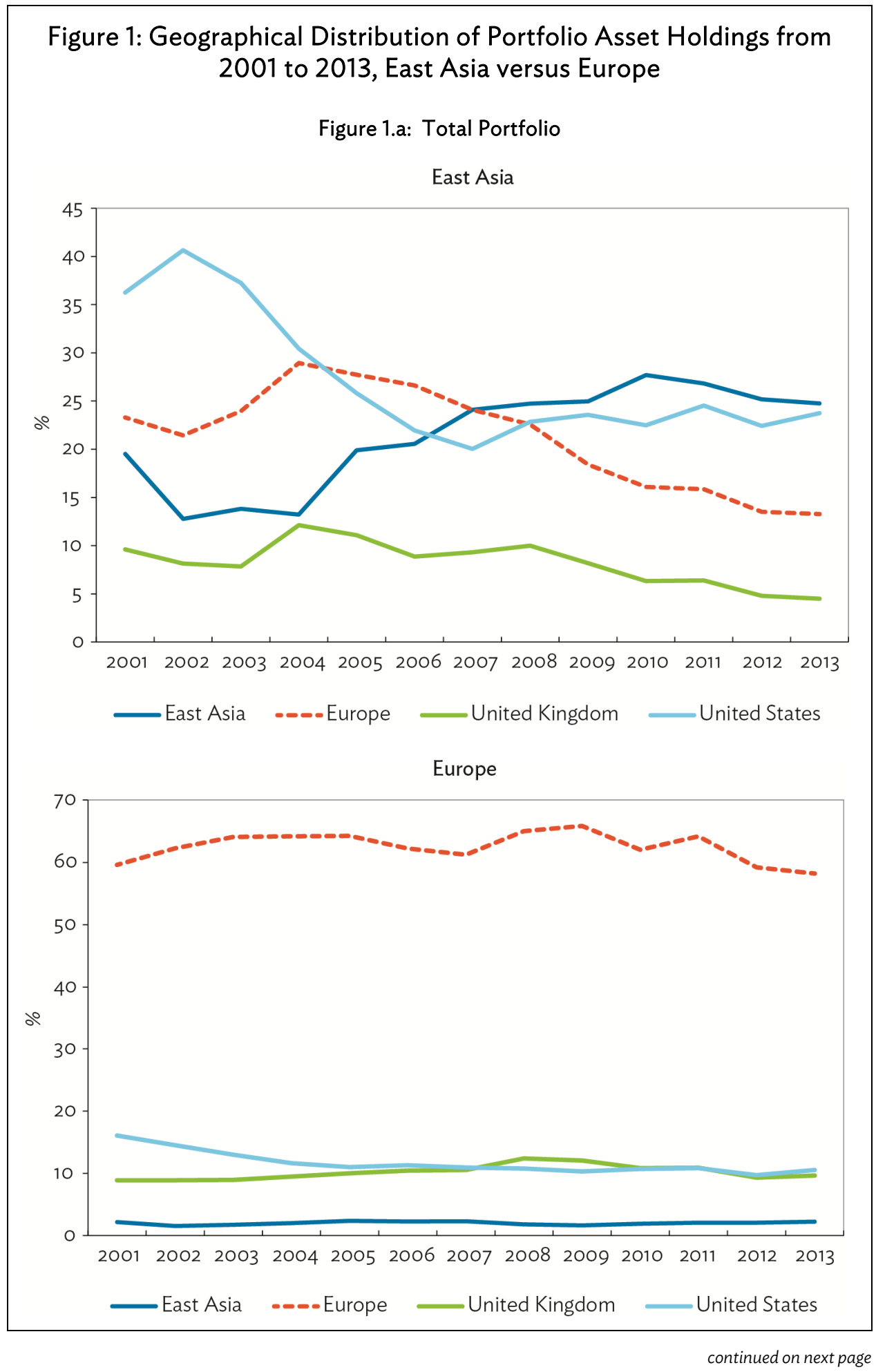


10 | ADB Economics Working Paper Series No. 444

Figure 1 continued

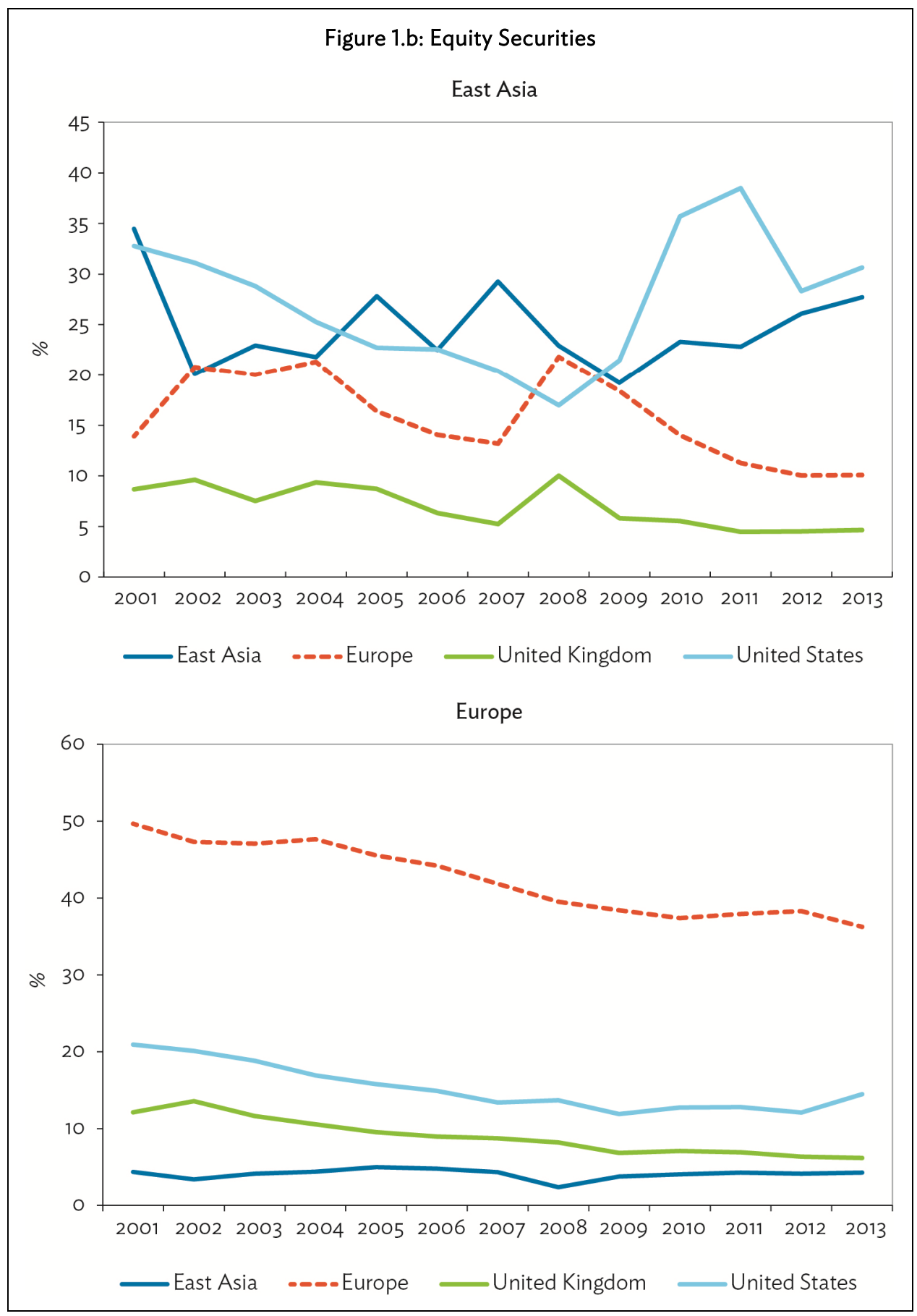

continued on next page 
Figure 1 continued

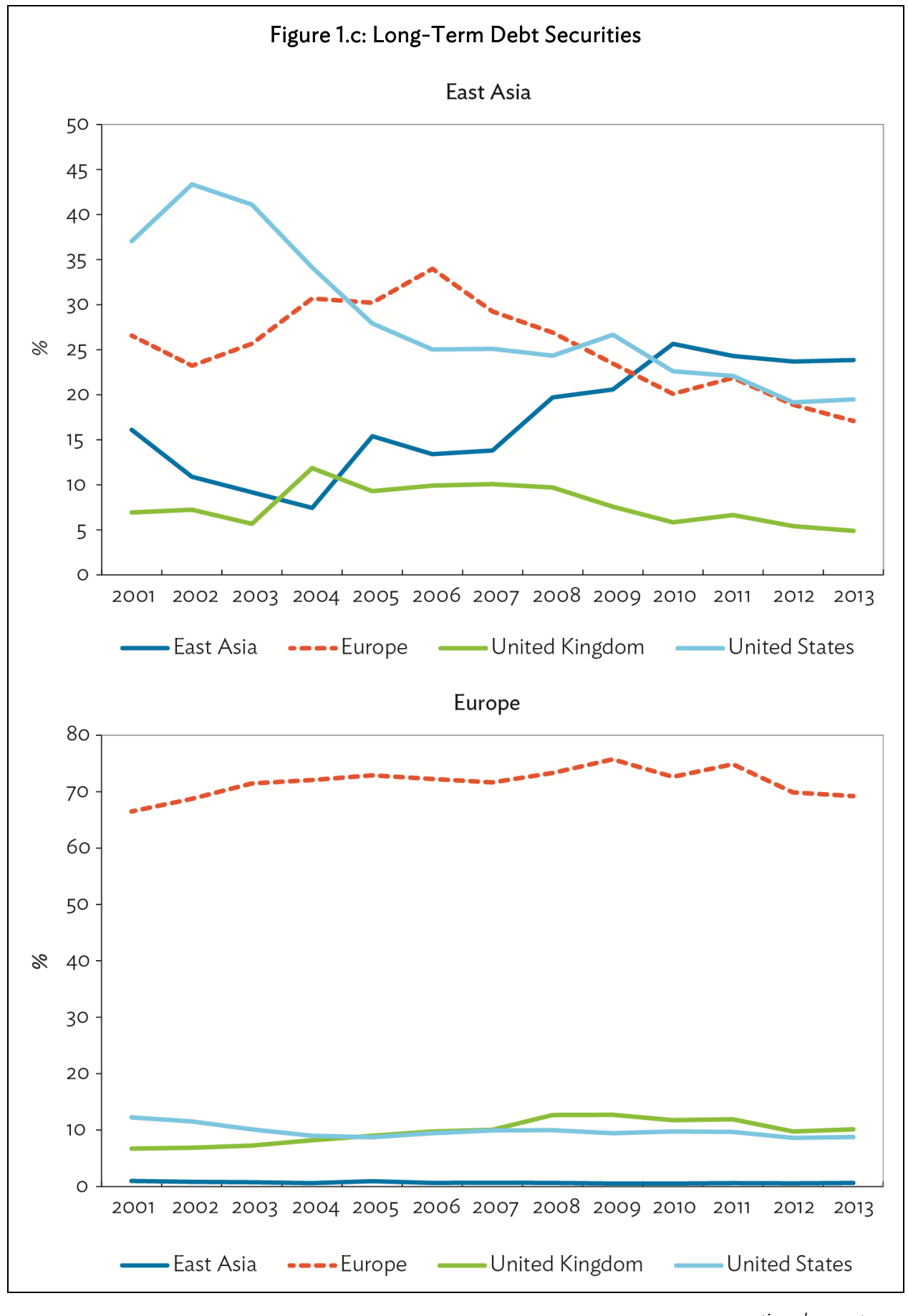

continued on next page 
12 | ADB Economics Working Paper Series No. 444

Figure 1 continued

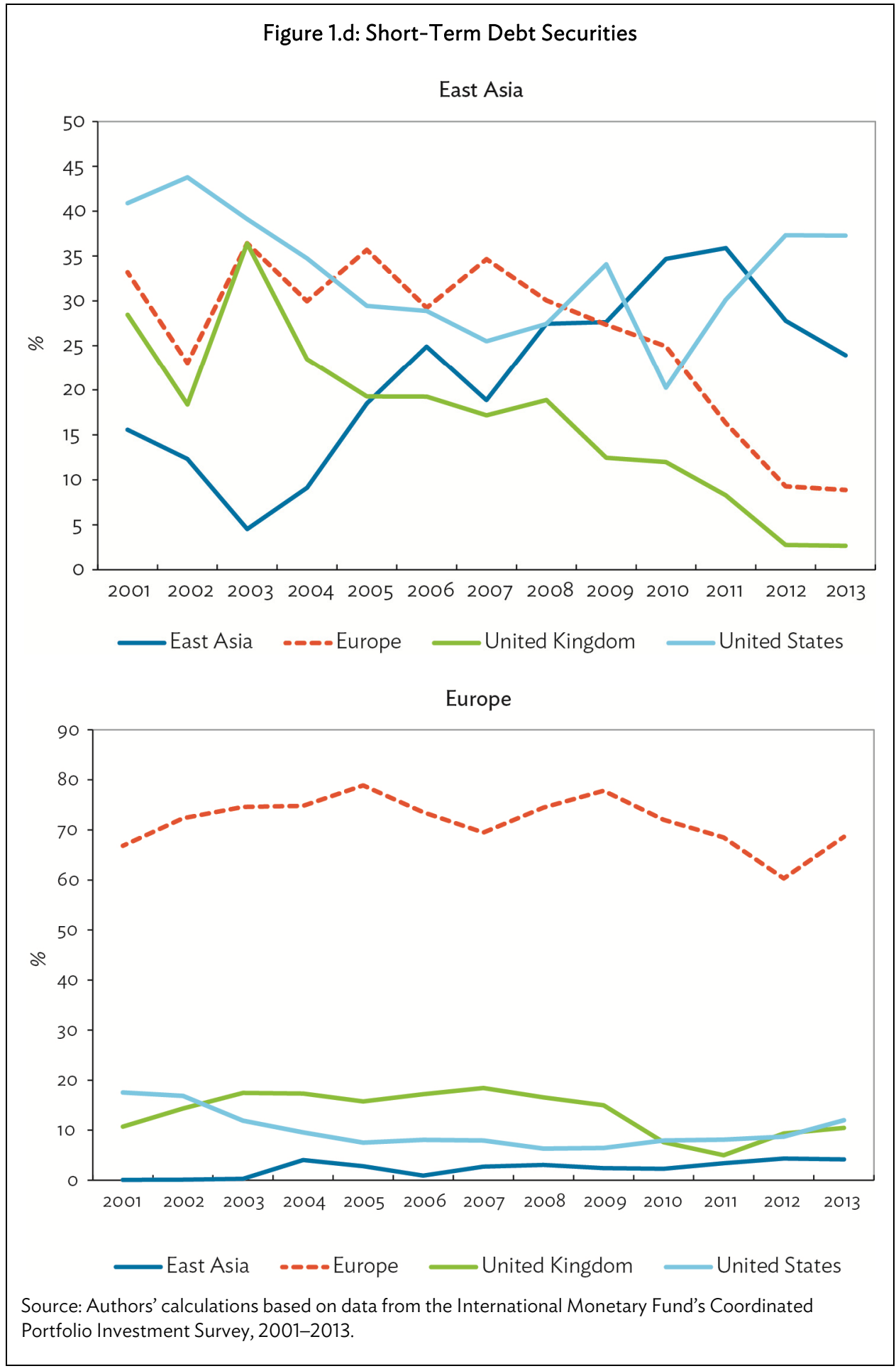


Overall, the figure implies that although there was an increasing trend in East Asia's intraregional share in asset holdings, the degree of regional integration in 2013 was still much lower than in Europe.

While the CPIS provides data on asset holdings only, we can interpret them as liability holdings. For example, if the Republic of Korea holds assets in Malaysia, we can interpret them as Malaysia's liability to the Republic of Korea. In this way, we can examine how the intraregional and global shares in liability holdings have evolved over time.

Figure 2 illustrates how the intraregional share and share of global markets in East Asian holdings of portfolio liabilities have evolved over time. Strikingly, there is no clear trend in shares of liability holdings. Figure 2.a shows the patterns of total portfolio liabilities in East Asia and Europe. In East Asia, the intraregional share has not increased at all, and the share of the global market has not declined. In contrast, for Europe, liabilities show generally the same pattern as assets, i.e. intraregional integration dominating integration with global markets.

Figures 2.b, 2.c, and 2.d show how the intraregional and global shares have evolved in liability holdings of equity securities, long-term debt securities, and short-term debt securities, respectively. Again there is no evidence of deepening regional integration in East Asia. Interestingly, however, while the intraregional share in liability holdings of equity securities is always less than the global share, the intraregional share in liability holdings of both long-term and short-term debt is quite sizable and greater than the global share. In contrast, in Europe, the intraregional share is always greater than any other share regardless of the type of portfolio investment. The intraregional share is the smallest for equity liabilities, but it is still around $50 \%$.

7 The time series averages of regional shares in liability holdings are similar to those in the asset holdings described in Table 1 and hence are not reported. 


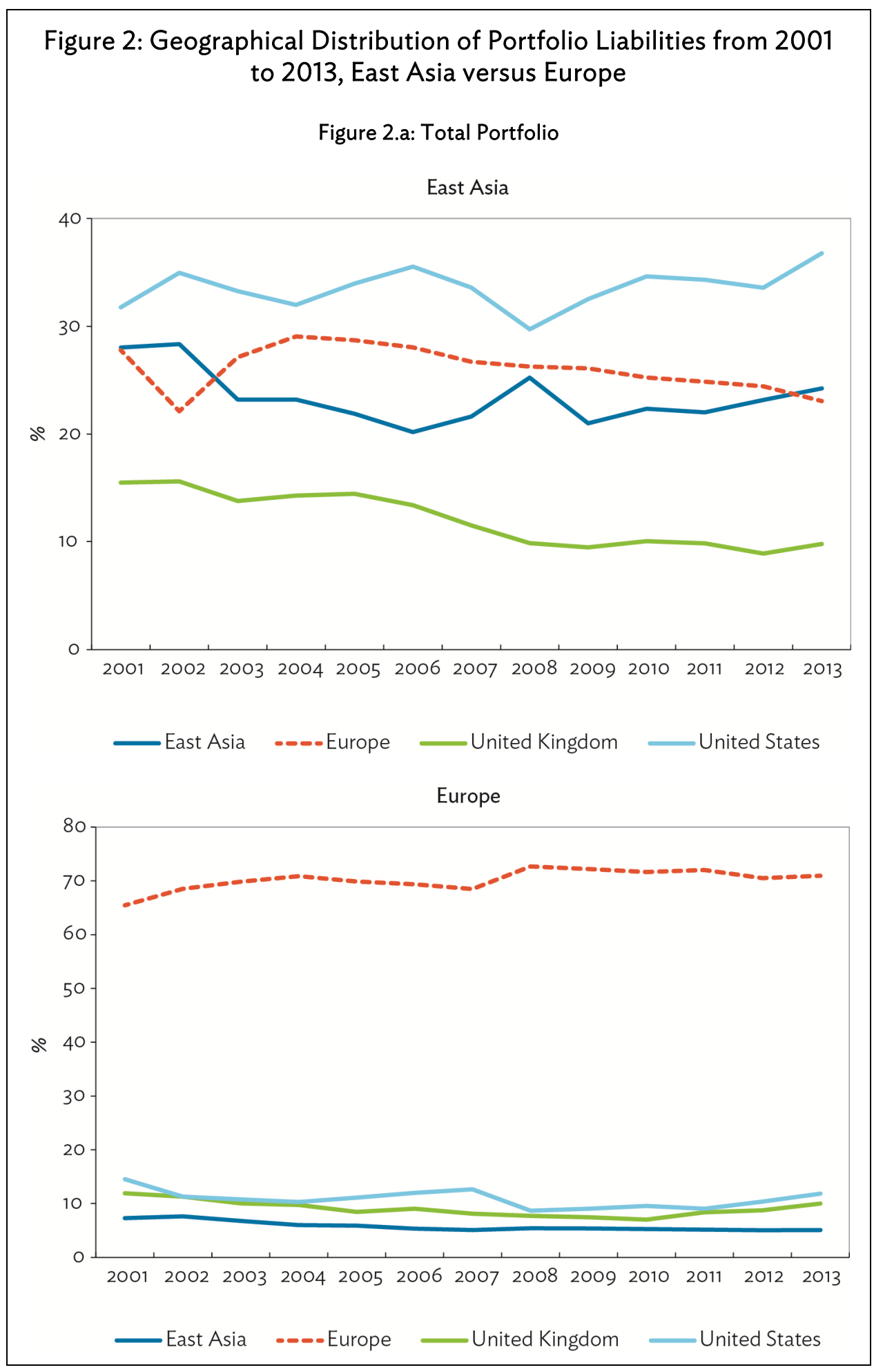


Figure 2 continued

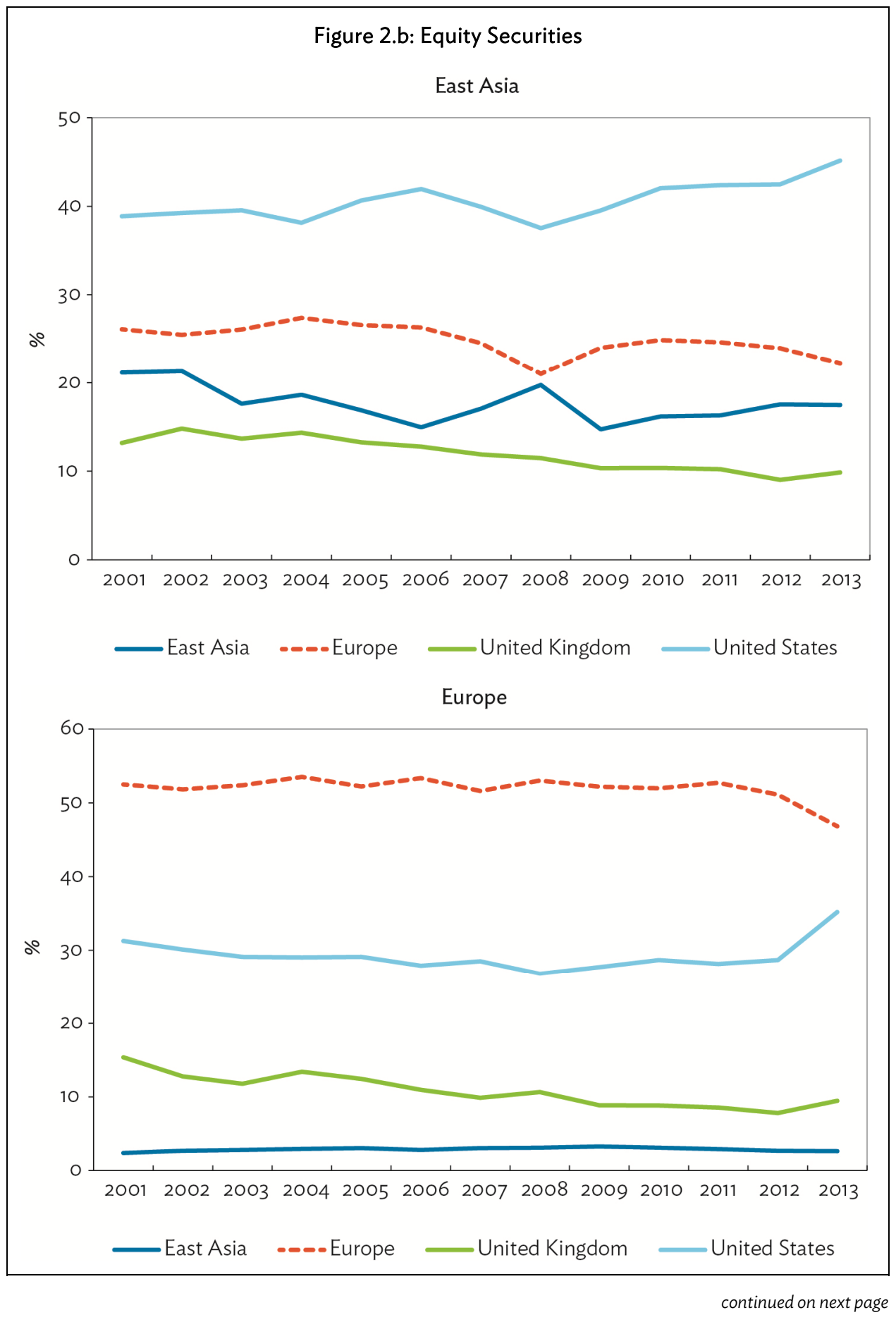


16 | ADB Economics Working Paper Series No. 444

Figure 2 continued

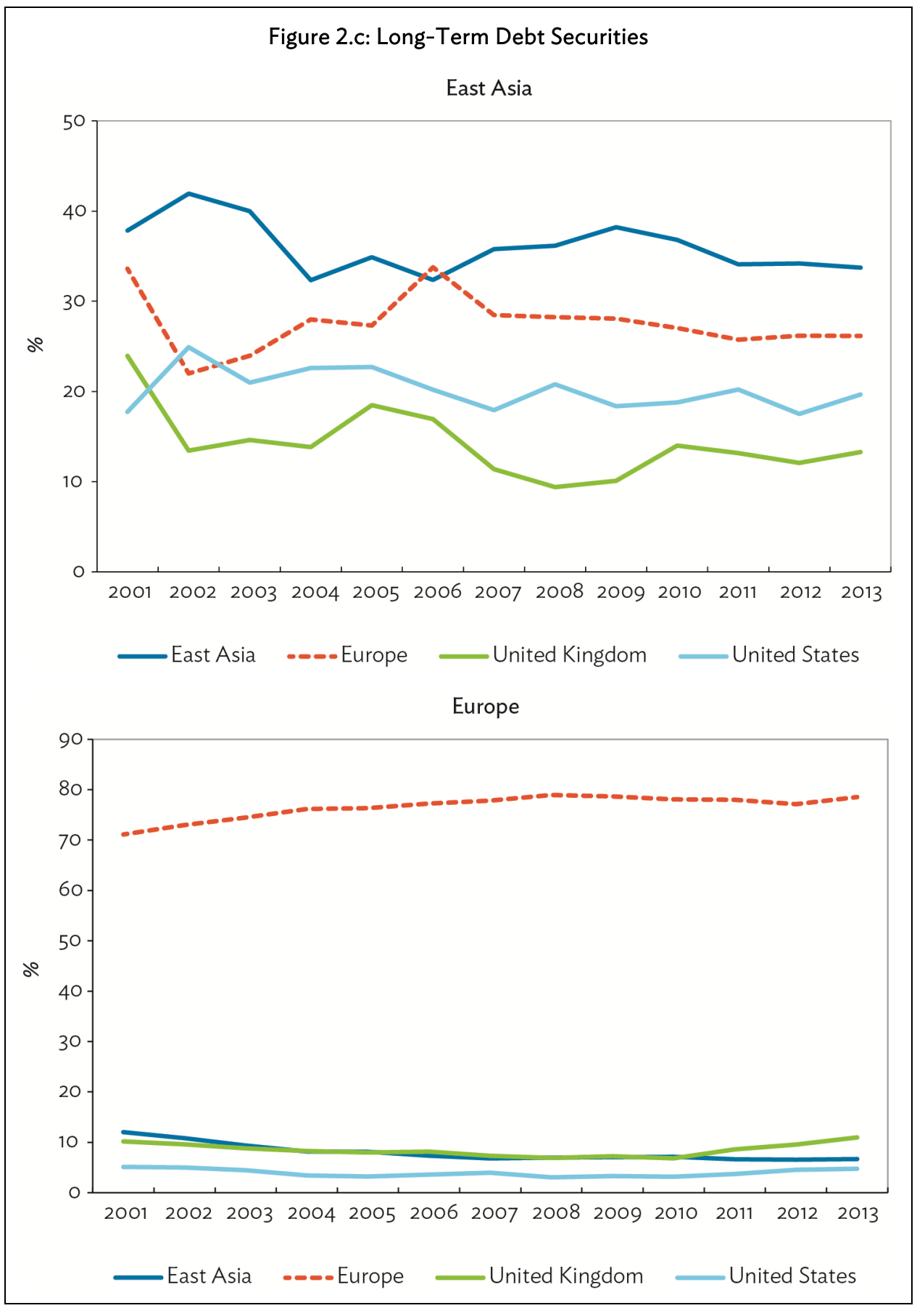

continued on next page 
Figure 2 continued

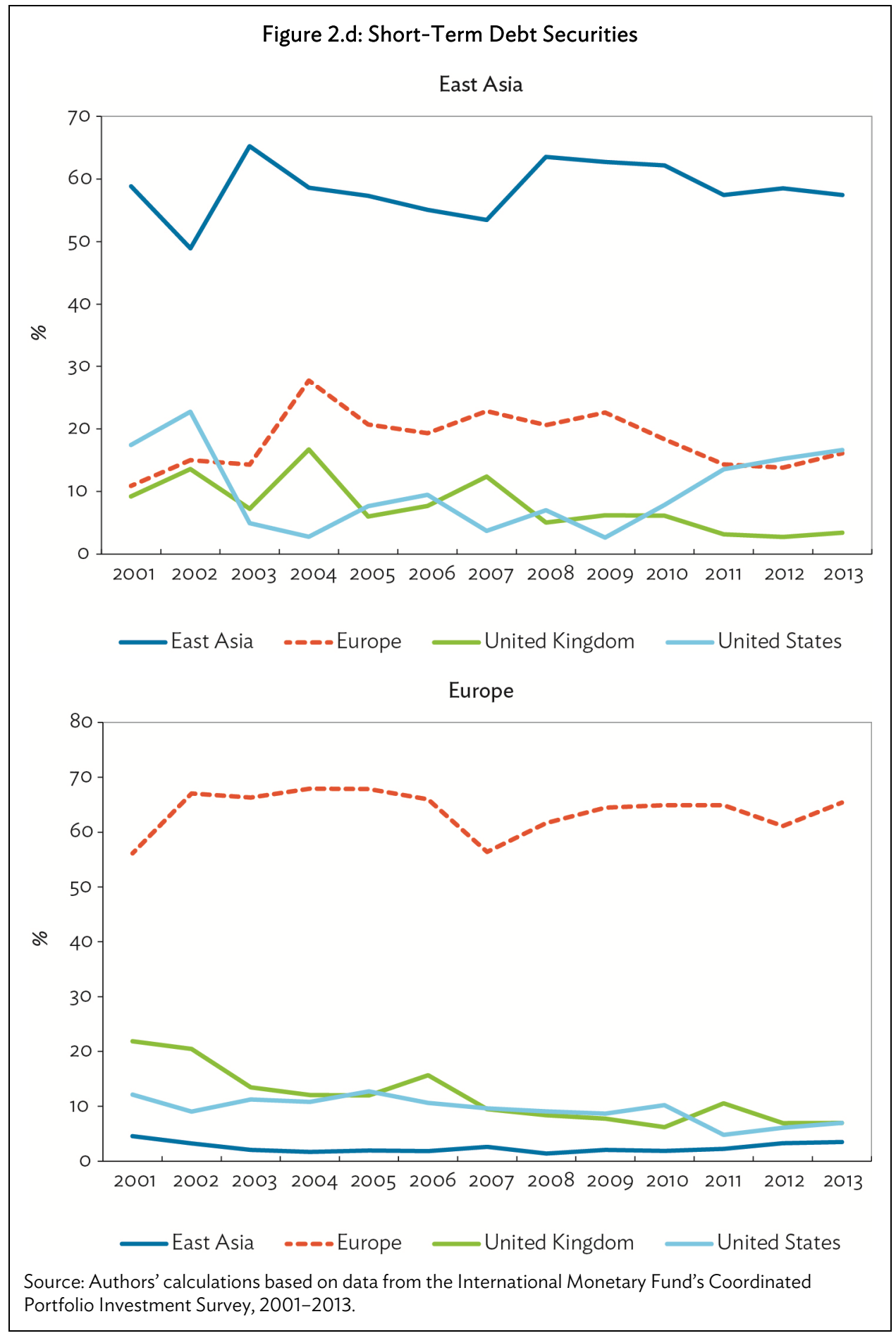




\section{A GRAVITY MODEL APPROACH TO MEASURING REGIONAL FINANCIAL INTEGRATION}

In order to more formally investigate the extent to which East Asian economies are financially integrated with others in the region, we used the gravity model. ${ }^{8}$ One advantage of this approach is that we can control for a number of other variables that influence financial integration. ${ }^{9}$ We follow Kim, Lee, and Shin (2008), and the formal equation we estimated is as follows:

$$
\begin{aligned}
\ln \left(\text { Assets }_{i j t}\right)= & \beta_{0}+\beta_{1} \ln \left(\text { Dist }_{i j}\right)+\beta_{2} \ln \left(\text { GDP }_{i t}\right)+\beta_{3} \ln \left(\text { GDP }_{j t}\right)+\beta_{4} \ln \left(\text { PCGDP }_{i t}\right) \\
& +\beta_{5} \ln \left(\text { PCGDP }_{j t}\right)+\beta_{6} \ln \left(\text { ComLan }_{i j}\right)+\beta_{7} \ln \left(\text { Border }_{i j}\right)+\beta_{8} \ln \left(\text { Area }_{i j}\right) \\
& +\beta_{8}{\text { EA } \text { single }_{i j}+\beta_{9} \text { EA }_{\text {pair }_{i j}}+\beta_{10} \text { Europe }_{\text {single }_{i j}}+\beta_{11} \text { Europe }_{\text {pair }}}_{i j}+\beta_{12} \text { Global }_{i j} \\
& +\beta_{13}{\text { EA } \text { global }_{i j}}+\beta_{14} \text { Europe }_{\text {global }_{i j}}+\beta_{15} \text { Year }_{t}+\varepsilon_{i j t}
\end{aligned}
$$

where $i$ and $j$ denote economies, $t$ denotes time, Assets $_{i j t}$ denotes the real asset holdings of $i$ in $j$ at time $t$, Dist $_{i j}$ is the distance between $i$ and $j$, GDP is real GDP, PCGDP is real per capita GDP, $\operatorname{ComLan}_{i j}$ is a binary variable which is unity if $i$ and $j$ have a common language, Border $_{i j}$ is a binary variable which is unity if $i$ and $j$ share a land border, Area $_{i j}$ is the land mass of $i$ and $j, Y_{\text {ear }}$ denotes a vector of binary variables which are unity in the specific year $t$.

In order to investigate the extent to which East Asian and European economies are financially integrated within their respective regions, we added four dummy variables: $E A_{\text {single }_{i j}}$, $E A_{\text {pair }_{i j}}$ Europe $_{\text {single }_{i j}}$, and Europe pair $_{i j} . E A_{\text {single }_{i j}}$ is a dummy variable that takes the value of 1 if either $i$ or $j$ belongs to East Asia, and $E A_{\text {pair }_{i j}}$ is a dummy variable that takes the value of 1 if both do. The estimated coefficient of $E A_{\text {single }_{i j}}$ captures the additional asset holdings of an East Asian economy in general. The estimated coefficient of $E A_{\text {pair }}$ ij represents the additional asset holdings when both economies are in East Asia. Hence the subtraction of the estimated coefficient of $E A_{\text {single }_{i j}}$ from that of $E A_{\text {pair }_{i j}}$ represents the degree of regional financial integration in East Asia relative to the region's integration with the rest of the world. Two additional dummy variables, Europe $_{\text {single }_{i j}}$, and Europe $_{\text {pair }}{ }_{i j}$ are similarly defined, and the subtraction of the estimated

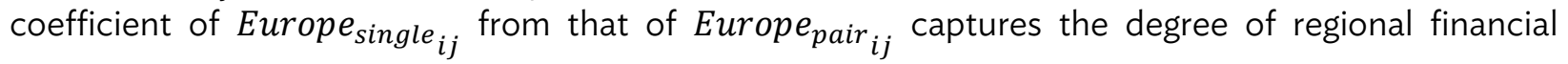
integration in Europe relative to the region's integration with the rest of the world.

We use asset holdings of (1) total portfolio investments, (2) equities, (3) long-term debt securities, and (4) short-term debt securities as the dependent variable. The summary statistics for the

8 While we used bilateral asset holdings as a dependent variable, the regression results are identical if bilateral liability holdings are used instead because the regression setup is completely symmetric.

9 While the gravity model to explain bilateral trade flows has a long history, it has not been widely used in explaining exchanges of financial assets. The main reason is that unlike goods, financial assets are weightless, and hence it is difficult to justify more exchanges among nearby countries. Portes and Rey (2005), however, found that a gravity model performs equally well in explaining asset exchanges. Rose and Spiegel (2004) also used the gravity equation to model sovereign lending. 
variables used in each regression are summarized in Table 2. The sample period is from 2001 to 2012,10 and the number of observations is over 10,000 for every regression.

Table 3 presents the results. Table 3.a shows the random-effects estimation results when total portfolio investments are used as a dependent variable." Column 1 reports the estimation results without dummy variables which is the baseline gravity model. The model fits the data very well; all the coefficients have the right signs and are statistically significant at the $1 \%$ level. In particular, the coefficient of distance is estimated to be negative which suggests that distance matters for financial transactions. Hence there is a bias toward trade with nearer countries not only in goods but also in assets. In this sense, our finding that East Asian economies are more integrated globally than regionally is somewhat puzzling. In this section, we investigate whether a more formal econometric analysis would reconfirm this peculiar feature of East Asia's trade in assets.

In column 2 we add both $E A_{\text {single }_{i j}}$ and $E A_{\text {pair }_{i j}}$ as additional regressors. We find that the coefficient of $E A_{\text {single }_{i j}}$ is negative and significant at the $1 \%$ level while the coefficient of $E A_{\text {pair }}{ }_{i j}$ is positive and significant at the $1 \%$ level. The subtraction of the estimated coefficient of $E A_{\text {single }}$ from that of $E A_{\text {pair }}$ ij 0.442 , which suggests that there is considerable regional integration. The estimated coefficient implies that the amount of asset holdings among East Asian economies is $1.56\left(=e^{0.442}\right)$ times as much as that between an East Asian economy and a non-East Asian one.

In column 3 we add Europe single $_{i j}$, and Europe pair $_{i j}$ as regressors. We find that the coefficient of Europe $_{\text {single }_{i j}}$ is negative and significant at the $1 \%$ level while the coefficient of Europe $_{\text {pair }}$ ij is positive and significant at the $1 \%$ level. The subtraction of the estimated coefficient of Europe $_{\text {single }_{i j}}$ from that of Europe pair $_{i j}$ is 2.051 which suggests that there is much deeper regional integration in Europe than in East Asia. The estimated coefficient implies that the amount of asset holdings among European countries is $7.8\left(=e^{2.051}\right)$ times as much as that between a European country and a non-European one.

In column 4 we also add dummies for integration with global financial markets: $E A_{\text {global }_{i j}}$,

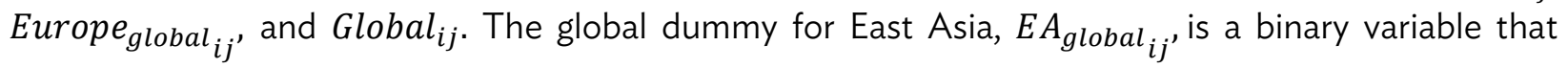
takes the value of 1 if the pair is between an East Asian economy and the global financial center and 0 otherwise. We assume that the US is the only global financial center. The global dummy for Europe, Europe $_{\text {global }_{i j}}$, is similarly defined. The estimated coefficients of the global dummies will capture the extent of the financial integration of East Asia and Europe with the US. Finally, Global $i j$ is a dummy that takes the value of 1 if either $i$ or $j$ is the global financial center, i.e. the US.

10 Since some of the explanatory variables are not available for 2013, we restricted the sample up to 2012 for the gravity regression.

11 Since the most dummy variables of interest are time invariable, we cannot adopt the fixed-effects estimation. 
Table 2: Summary Statistics, 2001-2012

\begin{tabular}{|c|c|c|c|c|c|c|c|c|}
\hline & \multicolumn{2}{|c|}{$\begin{array}{l}\text { (1) Total Portfolio } \\
(\mathrm{N}=12,625)\end{array}$} & \multicolumn{2}{|c|}{$\begin{array}{l}\text { (2) Equities } \\
(\mathrm{N}=10,736)\end{array}$} & \multicolumn{2}{|c|}{$\begin{array}{l}\text { (3) Long-Term Debts } \\
(\mathrm{N}=11,547)\end{array}$} & \multicolumn{2}{|c|}{$\begin{array}{l}\text { (4) Short-Term Debts } \\
(\mathrm{N}=12,625)\end{array}$} \\
\hline & Mean & Std. Dev & Mean & Std. Dev & Mean & Std. Dev & Mean & Std. Dev \\
\hline Portfolio & 2.348137 & 2.108392 & 1.841835 & 1.880468 & 2.017994 & 1.895786 & 0.691608 & 1.120513 \\
\hline Year & 2006.952 & 3.401787 & 2006.952 & 3.401787 & 2006.952 & 3.401787 & 2006.952 & 3.401787 \\
\hline Log of distance & 7.712633 & 1.061042 & 7.712633 & 1.061042 & 7.712633 & 1.061042 & 7.712633 & 1.061042 \\
\hline GDP in source country & $1.26 e+12$ & $2.79 e+12$ & $1.26 e+12$ & $2.79 e+12$ & $1.26 e+12$ & $2.79 e+12$ & $1.26 e+12$ & $2.79 e+12$ \\
\hline per capita GDP in source country & $3,1307.71$ & 21193.57 & 31307.71 & 21193.57 & 31307.71 & 21193.57 & $3,1307.71$ & 21193.57 \\
\hline GDP in host country & $1.34 e+12$ & $2.82 e+12$ & $1.34 e+12$ & $2.82 e+12$ & $1.34 \mathrm{e}+12$ & $2.82 e+12$ & $1.34 \mathrm{e}+12$ & $2.82 e+12$ \\
\hline per capita GDP in host country & $2,8347.5$ & 19700.92 & $2,8347.5$ & 19700.92 & $2,8347.5$ & 19700.92 & 28347.5 & 19700.92 \\
\hline Common language dummy & 0.208238 & 0.406064 & 0.208238 & 0.406064 & 0.208238 & 0.406064 & 0.208238 & 0.406064 \\
\hline Common land border dummy & 0.069149 & 0.253717 & 0.069149 & 0.253717 & 0.069149 & 0.253717 & 0.069149 & 0.253717 \\
\hline Log of area in pairs & 23.60275 & 3.663928 & 23.60275 & 3.663928 & 23.60275 & 3.663928 & 23.60275 & 3.663928 \\
\hline East Asia & 0.033743 & 0.180573 & 0.033743 & 0.180573 & 0.033743 & 0.180573 & 0.033743 & 0.180573 \\
\hline Europe & 0.141624 & 0.348678 & 0.141624 & 0.348678 & 0.141624 & 0.348678 & 0.141624 & 0.348678 \\
\hline
\end{tabular}

GDP = gross domestic product, Std. Dev = standard deviation.

Source: See Appendix Table A.1 for data sources. 
We found that the coefficients of $E A_{\text {global }_{i j}}$ and Europe global $_{i j}$ were positive and statistically significant at the $1 \%$ level. The coefficient of Europe $_{\text {global }_{i j}}$ is 2.617 which is larger than the coefficient of $E A_{\text {global }_{i j}}$ which is 1.867 . The estimates imply that the amount of asset holding by an East Asian economy in the US is $7.5\left(=e^{2.01}\right)$ times as much as that by an East Asian economy and another economy. ${ }^{12}$ The estimate for Europe is $19.2\left(=e^{2.95}\right)$ times. ${ }^{13}$ While European economies are thus more globally integrated than those in East Asia in absolute terms, if we measure global integration relative to regional integration, the picture is different. More specifically, the global integration of East Asian economies is $4.7(=7.5 / 1.6)$ times greater than their regional integration, while the global integration of European countries is $2.5(=19.2 / 7.8)$ times greater than their regional integration. Our econometric results thus reconfirm that East Asian economies are financially more integrated globally than regionally relative to Europe.

In column 5 we report the same regression results as those in column 4 except that the global dummy variable is redefined by assuming that both the US and the UK, not just the US, are global financial centers. The estimated coefficients of $E A_{\text {global }_{i j}}$ and Europe $_{\text {global }_{i j}}$ are again positive, large, and statistically significant at the $1 \%$ level, and their values are essentially the same. The results again indicate that East Asian economies are financially more integrated with global financial centers than with each other.

Table 3.b shows the same regression results when the dependent variable is equity securities. Let's interpret our results based on the estimates in column 4. They suggest that the amount of asset holdings in East Asia is $1.6\left(=e^{.499}\right)$ times as much as that between an East Asian economy and a nonEast Asian economy. By way of comparison, the amount of asset holdings among European economies is $3\left(=e^{1.117}\right)$ times as much as that between a European economy and a non-European economy. The results also suggest that the amount of asset holdings between an East Asian economy and the US is $7.7\left(=e^{2.047}\right)$ times as much as that between an East Asian economy and another economy. The corresponding figure for Europe is $23.1\left(=e^{3.149}\right)$ times. These results suggest that as far as equity securities are concerned, the bias for global integration is less severe in East Asia and Europe.

Tables 3.c and 3.d show the regression results when the dependent variables are long-term debt securities and short-term securities, respectively. The results suggest that the global bias in East Asia is driven to a large extent by long-term securities. In Table 3.c, the amount of asset holdings among East Asian economies is $1.5\left(=e^{.423}\right)$ times as much as that between an East Asian economy and a non-East Asian economy. On the other hand, the amount of asset holdings between an East Asian economy and the US is $3.9\left(=e^{1.349}\right)$ times as much as that between an East Asian economy and another economy. Hence East Asians trade long-term debt securities 2.5 times more globally than regionally. The corresponding figures for Europe are $8.7\left(=e^{2.164}\right)$ times for intraregional holdings and $10.6\left(=e^{2.362}\right)$ times for global holdings, which suggest that Europeans trade 1.2 times more globally than regionally.

Interestingly, we fail to observe a similar pattern for global bias in the trade of short-term debt securities in Table 3.d. Even though there has been relatively more regional trade in short-term debt securities in East Asia, the absolute level of regional trade is very small compared to that in Europe which explains why the coefficient of $E A_{\text {pair }_{i j}}$ is statistically not significant.

12 From Table 3.a, $1.867-(-0.145)=2.01$

13 From Table 3.a, 2.617 $-(-0.337)=2.95$ 
Table 3: Portfolio Estimation with Regional and Global Dummies

\begin{tabular}{|c|c|c|c|c|c|}
\hline \multirow[b]{2}{*}{ Dependent Variable } & \multicolumn{5}{|c|}{ Log of Real Total Portfolio, 2001-2012 } \\
\hline & {$[1]$} & {$[2]$} & [3] & {$[4]$} & {$[5]$} \\
\hline \multirow[t]{2}{*}{ Log distance } & $-0.225^{* * *}$ & $-0.204^{* * *}$ & $-0.130^{* * *}$ & $-0.144^{* * *}$ & $-0.139^{* * *}$ \\
\hline & $(0.018)$ & $(0.019)$ & $(0.018)$ & $(0.018)$ & $(0.018)$ \\
\hline \multirow[t]{2}{*}{ GDP in source } & $0.341^{* * *}$ & $0.347^{* * *}$ & $0.352^{* * *}$ & $0.323^{* * *}$ & $0.315^{* * *}$ \\
\hline & $(0.012)$ & $(0.013)$ & $(0.014)$ & $(0.013)$ & $(0.013)$ \\
\hline \multirow[t]{2}{*}{ GDP in host } & $0.413^{* * *}$ & $0.420^{* * *}$ & $0.409^{* * *}$ & $0.383^{* * *}$ & $0.376^{* * *}$ \\
\hline & $(0.013)$ & $(0.014)$ & $(0.014)$ & $(0.013)$ & $(0.013)$ \\
\hline \multirow{2}{*}{$\begin{array}{l}\text { Per capita GDP } \\
\text { in source }\end{array}$} & $0.451^{* * *}$ & $0.441^{* * *}$ & $0.435^{* * *}$ & $0.426^{* * *}$ & $0.435^{* * *}$ \\
\hline & $(0.016)$ & $(0.018)$ & $(0.017)$ & $(0.016)$ & $(0.016)$ \\
\hline \multirow{2}{*}{$\begin{array}{l}\text { Per capita GDP } \\
\text { in host }\end{array}$} & $0.212^{* * *}$ & $0.206^{* * *}$ & $0.193^{* * *}$ & $0.188^{* * *}$ & $0.197^{* * *}$ \\
\hline & $(0.015)$ & $(0.016)$ & $(0.015)$ & $(0.014)$ & $(0.014)$ \\
\hline \multirow[t]{2}{*}{ Common language } & $0.439^{* * *}$ & $0.432^{* * *}$ & $0.405^{* * *}$ & $0.361^{* * *}$ & $0.330^{* * *}$ \\
\hline & $(0.037)$ & $(0.037)$ & $(0.037)$ & $(0.035)$ & $(0.034)$ \\
\hline \multirow[t]{2}{*}{ Border } & $0.731^{* * *}$ & $0.751^{* * *}$ & $0.674^{* * *}$ & $0.689^{* * *}$ & $0.724^{* * *}$ \\
\hline & $(0.100)$ & $(0.101)$ & $(0.091)$ & $(0.091)$ & $(0.092)$ \\
\hline \multirow[t]{2}{*}{ Area in pair } & $-0.080^{* * *}$ & $-0.086^{* * *}$ & $-0.090^{* * *}$ & $-0.088^{* * *}$ & $-0.083^{* * *}$ \\
\hline & $(0.007)$ & $(0.008)$ & $(0.008)$ & $(0.007)$ & $(0.007)$ \\
\hline \multirow[t]{2}{*}{ East Asia single } & & $-0.113^{* * *}$ & $-0.193^{* * *}$ & $-0.145^{* * *}$ & $-0.167^{* * *}$ \\
\hline & & $(0.043)$ & $(0.043)$ & $(0.042)$ & $(0.041)$ \\
\hline \multirow[t]{2}{*}{ East Asia pair } & & $0.329^{* * *}$ & $0.357^{* * *}$ & $0.411^{* * *}$ & $0.459^{* * *}$ \\
\hline & & $(0.120)$ & $(0.120)$ & $(0.119)$ & $(0.120)$ \\
\hline \multirow[t]{2}{*}{ Europe single } & & & $-0.370^{* * *}$ & $-0.337^{* * *}$ & $-0.365^{* * *}$ \\
\hline & & & $(0.032)$ & $(0.031)$ & $(0.031)$ \\
\hline \multirow[t]{2}{*}{ Europe pair } & & & $1.681^{* * *}$ & $1.773^{* * *}$ & $1.513^{* * *}$ \\
\hline & & & $(0.097)$ & $(0.098)$ & $(0.101)$ \\
\hline \multirow[t]{2}{*}{ Global (US) } & & & & $0.241^{* *}$ & \\
\hline & & & & $(0.122)$ & \\
\hline \multirow[t]{2}{*}{ East Asia global (US) } & & & & $1.867^{* * *}$ & \\
\hline & & & & $(0.313)$ & \\
\hline \multirow[t]{2}{*}{ Europe global (US) } & & & & $2.617^{* * *}$ & \\
\hline & & & & $(0.237)$ & \\
\hline \multirow[t]{2}{*}{ Global (US \& UK) } & & & & & $0.238^{* * *}$ \\
\hline & & & & & $(0.072)$ \\
\hline \multirow[t]{2}{*}{ East Asia global (US \& UK) } & & & & & $1.752^{* * *}$ \\
\hline & & & & & $(0.218)$ \\
\hline \multirow[t]{2}{*}{ Europe global (US \& UK) } & & & & & $1.742^{* * *}$ \\
\hline & & & & & $(0.200)$ \\
\hline Observations & 41,015 & 41,015 & 41,015 & 41,015 & 41,015 \\
\hline R-squared & 0.529 & 0.528 & 0.569 & 0.603 & 0.607 \\
\hline
\end{tabular}


Table 3 continued

Table 3.b: Equity Securities

\begin{tabular}{|c|c|c|c|c|c|}
\hline \multirow[b]{2}{*}{ Dependent Variable } & \multicolumn{5}{|c|}{ Log of Real Equity, 2001-2012 } \\
\hline & [1] & [2] & {$[3]$} & {$[4]$} & [5] \\
\hline \multirow[t]{2}{*}{ Log distance } & $-0.115^{* * *}$ & $-0.093^{* * *}$ & $-0.078^{* * *}$ & $-0.089^{* * *}$ & $-0.083^{* * *}$ \\
\hline & $(0.019)$ & $(0.020)$ & $(0.020)$ & $(0.019)$ & $(0.019)$ \\
\hline \multirow[t]{2}{*}{ GDP in source } & $0.300^{* * *}$ & $0.305^{* * *}$ & $0.336^{* * *}$ & $0.312^{* * *}$ & $0.302^{* * *}$ \\
\hline & $(0.012)$ & $(0.013)$ & $(0.015)$ & $(0.014)$ & $(0.014)$ \\
\hline \multirow[t]{2}{*}{ GDP in host } & $0.324^{* * *}$ & $0.330^{* * *}$ & $0.346^{* * *}$ & $0.321^{* * *}$ & $0.311^{* * *}$ \\
\hline & $(0.013)$ & $(0.014)$ & $(0.015)$ & $(0.014)$ & $(0.014)$ \\
\hline \multirow{2}{*}{$\begin{array}{l}\text { Per capita GDP } \\
\text { in source }\end{array}$} & $0.438^{* * *}$ & $0.432^{* * *}$ & $0.430^{* * *}$ & $0.421^{* * *}$ & $0.428^{* * *}$ \\
\hline & $(0.017)$ & $(0.017)$ & $(0.017)$ & $(0.017)$ & $(0.017)$ \\
\hline \multirow{2}{*}{$\begin{array}{l}\text { Per capita GDP } \\
\text { in host }\end{array}$} & $0.214^{* * *}$ & $0.209^{* * *}$ & $0.199^{* * *}$ & $0.191^{* * *}$ & $0.198^{* * *}$ \\
\hline & $(0.014)$ & $(0.015)$ & $(0.014)$ & $(0.014)$ & $(0.014)$ \\
\hline \multirow[t]{2}{*}{ Common language } & $0.488^{* * *}$ & $0.481^{* * *}$ & $0.436^{* * *}$ & $0.404^{* * *}$ & $0.376^{* * *}$ \\
\hline & $(0.041)$ & $(0.041)$ & $(0.041)$ & $(0.039)$ & $(0.038)$ \\
\hline \multirow[t]{2}{*}{ Border } & $0.732^{* * *}$ & $0.753^{* * *}$ & $0.682^{* * *}$ & $0.693^{* * *}$ & $0.730^{* * *}$ \\
\hline & $(0.102)$ & $(0.102)$ & $(0.100)$ & $(0.101)$ & $(0.101)$ \\
\hline \multirow[t]{2}{*}{ Area in pair } & $-0.057^{* * *}$ & $-0.062^{* * *}$ & $-0.075^{* * *}$ & $-0.072^{* * *}$ & $-0.068^{* * *}$ \\
\hline & $(0.007)$ & $(0.008)$ & $(0.008)$ & $(0.007)$ & $(0.007)$ \\
\hline \multirow[t]{2}{*}{ East Asia single } & & $-0.115^{* *}$ & $-0.230^{* * *}$ & $-0.200^{* * *}$ & $-0.227^{* * *}$ \\
\hline & & $(0.045)$ & $(0.047)$ & $(0.044)$ & $(0.044)$ \\
\hline \multirow[t]{2}{*}{ East Asia pair } & & $0.368^{* * *}$ & $0.257^{* *}$ & $0.299^{* * *}$ & $0.360^{* * *}$ \\
\hline & & $(0.117)$ & $(0.117)$ & $(0.115)$ & $(0.115)$ \\
\hline \multirow[t]{2}{*}{ Europe single } & & & $-0.438^{* * *}$ & $-0.431^{* * *}$ & $-0.433^{* * *}$ \\
\hline & & & $(0.036)$ & $(0.034)$ & $(0.034)$ \\
\hline \multirow[t]{2}{*}{ Europe pair } & & & $0.593^{* * *}$ & $0.686^{* * *}$ & $0.401^{* * *}$ \\
\hline & & & $(0.101)$ & $(0.101)$ & $(0.098)$ \\
\hline \multirow[t]{2}{*}{ Global (US) } & & & & -0.064 & \\
\hline & & & & $(0.131)$ & \\
\hline \multirow[t]{2}{*}{ East Asia global (US) } & & & & $1.847^{* * *}$ & \\
\hline & & & & $(0.370)$ & \\
\hline \multirow[t]{2}{*}{ Europe global (US) } & & & & $2.708^{* * *}$ & \\
\hline & & & & $(0.253)$ & \\
\hline \multirow[t]{2}{*}{ Global (US \& UK) } & & & & & 0.001 \\
\hline & & & & & $(0.078)$ \\
\hline \multirow[t]{2}{*}{ East Asia global (US \& UK) } & & & & & $1.762^{* * *}$ \\
\hline & & & & & $(0.247)$ \\
\hline \multirow[t]{2}{*}{ Europe global (US \& UK) } & & & & & $2.099^{* * *}$ \\
\hline & & & & & $(0.187)$ \\
\hline Observations & 30,485 & 30,485 & 30,485 & 30,485 & 30,485 \\
\hline R-squared & 0.458 & 0.458 & 0.472 & 0.514 & 0.527 \\
\hline
\end{tabular}


24 | ADB Economics Working Paper Series No. 444

Table 3 continued

Table 3.c: Long-Term Debt Securities

\begin{tabular}{|c|c|c|c|c|c|}
\hline \multirow[b]{2}{*}{ Dependent Variable } & \multicolumn{5}{|c|}{ Log of Real Long-Term Debt, 2001-2012 } \\
\hline & {$[1]$} & [2] & [3] & [4] & [5] \\
\hline \multirow[t]{2}{*}{ Log distance } & $-0.269^{* * *}$ & $-0.234^{* * *}$ & $-0.139^{* * *}$ & $-0.154^{* * *}$ & $-0.148^{* * *}$ \\
\hline & $(0.018)$ & $(0.018)$ & $(0.016)$ & $(0.016)$ & $(0.016)$ \\
\hline \multirow[t]{2}{*}{ GDP in source } & $0.275^{* * *}$ & $0.296^{* * *}$ & $0.290^{* * *}$ & $0.258^{* * *}$ & $0.248^{* * *}$ \\
\hline & $(0.012)$ & $(0.013)$ & $(0.013)$ & $(0.013)$ & $(0.013)$ \\
\hline \multirow[t]{2}{*}{ GDP in host } & $0.358^{* * *}$ & $0.379^{* * *}$ & $0.359^{* * *}$ & $0.331^{* * *}$ & $0.323^{* * *}$ \\
\hline & $(0.013)$ & $(0.014)$ & $(0.014)$ & $(0.013)$ & $(0.013)$ \\
\hline \multirow{2}{*}{$\begin{array}{l}\text { Per capita GDP } \\
\text { in source }\end{array}$} & $0.406^{* * *}$ & $0.376^{* * *}$ & $0.360^{* * *}$ & $0.353^{* * *}$ & $0.366^{* * *}$ \\
\hline & $(0.018)$ & $(0.019)$ & $(0.018)$ & $(0.017)$ & $(0.017)$ \\
\hline \multirow{2}{*}{$\begin{array}{l}\text { Per capita GDP } \\
\text { in host }\end{array}$} & $0.174^{* * *}$ & $0.155^{* * *}$ & $0.141^{* * *}$ & $0.137^{* * *}$ & $0.149^{* * *}$ \\
\hline & $(0.013)$ & $(0.014)$ & $(0.013)$ & $(0.013)$ & $(0.013)$ \\
\hline \multirow[t]{2}{*}{ Common language } & $0.285^{* * *}$ & $0.280^{* * *}$ & $0.260^{* * *}$ & $0.212^{* * *}$ & $0.175^{* * *}$ \\
\hline & $(0.038)$ & $(0.038)$ & $(0.037)$ & $(0.034)$ & $(0.035)$ \\
\hline \multirow[t]{2}{*}{ Border } & $0.573^{* * *}$ & $0.604^{* * *}$ & $0.530^{* * *}$ & $0.551^{* * *}$ & $0.588^{* * *}$ \\
\hline & $(0.108)$ & $(0.108)$ & $(0.091)$ & $(0.090)$ & $(0.092)$ \\
\hline \multirow[t]{2}{*}{ Area in pair } & $-0.064^{* * *}$ & $-0.079^{* * *}$ & $-0.081^{* * *}$ & $-0.078^{* * *}$ & $-0.072^{* * *}$ \\
\hline & $(0.007)$ & $(0.008)$ & $(0.007)$ & $(0.007)$ & $(0.007)$ \\
\hline \multirow[t]{2}{*}{ East Asia single } & & $-0.221^{* * *}$ & $-0.262^{* * *}$ & $-0.193^{* * *}$ & $-0.208^{* * *}$ \\
\hline & & $(0.044)$ & $(0.044)$ & $(0.042)$ & $(0.042)$ \\
\hline \multirow[t]{2}{*}{ East Asia pair } & & 0.135 & $0.184^{*}$ & $0.230^{* *}$ & $0.280^{* * *}$ \\
\hline & & $(0.111)$ & (0.109) & $(0.107)$ & $(0.107)$ \\
\hline \multirow[t]{2}{*}{ Europe single } & & & $-0.305^{* * *}$ & $-0.260^{* * *}$ & $-0.291^{* * *}$ \\
\hline & & & $(0.031)$ & $(0.030)$ & $(0.029)$ \\
\hline \multirow[t]{2}{*}{ Europe pair } & & & $1.816^{* * *}$ & $1.904^{* * *}$ & $1.693^{* * *}$ \\
\hline & & & $(0.097)$ & $(0.098)$ & $(0.101)$ \\
\hline \multirow[t]{2}{*}{ Global (US) } & & & & $0.329^{* * *}$ & \\
\hline & & & & $(0.112)$ & \\
\hline \multirow[t]{2}{*}{ East Asia global (US) } & & & & $1.156^{* * *}$ & \\
\hline & & & & $(0.341)$ & \\
\hline \multirow[t]{2}{*}{ Europe global (US) } & & & & $2.102^{* * *}$ & \\
\hline & & & & $(0.253)$ & \\
\hline \multirow[t]{2}{*}{ Global (US \& UK) } & & & & & $0.315^{* * *}$ \\
\hline & & & & & $(0.067)$ \\
\hline \multirow[t]{2}{*}{ East Asia global (US \& UK) } & & & & & $1.118^{* * *}$ \\
\hline & & & & & $(0.223)$ \\
\hline \multirow[t]{2}{*}{ Europe global (US \& UK) } & & & & & $1.346^{* * *}$ \\
\hline & & & & & $(0.199)$ \\
\hline Observations & 31,778 & 31,778 & 31,778 & 31,778 & 31,778 \\
\hline R-squared & 0.514 & 0.513 & 0.573 & 0.604 & 0.606 \\
\hline
\end{tabular}


Table 3 continued

Table 3.d: Short-Term Debt Securities

\begin{tabular}{|c|c|c|c|c|c|}
\hline \multirow[b]{2}{*}{ Dependent Variable } & \multicolumn{5}{|c|}{ Log of Real Short-Term Debt, 2001-2012 } \\
\hline & [1] & [2] & [3] & {$[4]$} & [5] \\
\hline \multirow[t]{2}{*}{ Log distance } & $-0.104^{* * *}$ & $-0.097^{* * *}$ & $-0.054^{* * *}$ & $-0.070^{* * *}$ & $-0.062^{* * *}$ \\
\hline & $(0.017)$ & $(0.018)$ & $(0.017)$ & $(0.017)$ & $(0.017)$ \\
\hline \multirow[t]{2}{*}{ GDP in source } & $0.110^{* * *}$ & $0.113^{* * *}$ & $0.113^{* * *}$ & $0.083^{* * *}$ & $0.072^{* * *}$ \\
\hline & $(0.011)$ & $(0.012)$ & $(0.013)$ & $(0.012)$ & $(0.012)$ \\
\hline \multirow[t]{2}{*}{ GDP in host } & $0.166^{* * *}$ & $0.169^{* * *}$ & $0.166^{* * *}$ & $0.140^{* * *}$ & $0.131^{* * *}$ \\
\hline & $(0.012)$ & $(0.013)$ & $(0.014)$ & $(0.013)$ & $(0.012)$ \\
\hline \multirow{2}{*}{$\begin{array}{l}\text { Per capita GDP } \\
\text { in source }\end{array}$} & $0.187^{* * *}$ & $0.184^{* * *}$ & $0.174^{* * *}$ & $0.161^{* * *}$ & $0.173^{* * *}$ \\
\hline & $(0.016)$ & $(0.017)$ & $(0.017)$ & $(0.016)$ & $(0.017)$ \\
\hline \multirow{2}{*}{$\begin{array}{l}\text { Per capita GDP } \\
\text { in host }\end{array}$} & $0.090^{* * *}$ & $0.089^{* * *}$ & $0.083^{* * *}$ & $0.075^{* * *}$ & $0.089^{* * *}$ \\
\hline & $(0.011)$ & $(0.012)$ & $(0.012)$ & $(0.011)$ & $(0.012)$ \\
\hline \multirow[t]{2}{*}{ Common language } & $0.294^{* * *}$ & $0.293^{* * *}$ & $0.285^{* * *}$ & $0.253^{* * *}$ & $0.225^{* * *}$ \\
\hline & $(0.044)$ & $(0.044)$ & $(0.044)$ & $(0.041)$ & $(0.041)$ \\
\hline \multirow[t]{2}{*}{ Border } & $0.384^{* * *}$ & $0.391^{* * *}$ & $0.384^{* * *}$ & $0.399^{* * *}$ & $0.444^{* * *}$ \\
\hline & $(0.105)$ & $(0.105)$ & $(0.103)$ & $(0.103)$ & $(0.101)$ \\
\hline \multirow[t]{2}{*}{ Area in pair } & $-0.026^{* * *}$ & $-0.029^{* * *}$ & $-0.032^{* * *}$ & $-0.031^{* * *}$ & $-0.025^{* * *}$ \\
\hline & $(0.006)$ & $(0.007)$ & $(0.007)$ & $(0.007)$ & $(0.007)$ \\
\hline \multirow[t]{2}{*}{ East Asia single } & & -0.037 & -0.066 & 0.014 & 0.008 \\
\hline & & $(0.039)$ & $(0.041)$ & $(0.036)$ & $(0.037)$ \\
\hline \multirow[t]{2}{*}{ East Asia pair } & & 0.073 & 0.079 & 0.104 & 0.144 \\
\hline & & $(0.103)$ & $(0.102)$ & $(0.100)$ & $(0.100)$ \\
\hline \multirow[t]{2}{*}{ Europe single } & & & $-0.137^{* * *}$ & $-0.089^{* * *}$ & $-0.121^{* * *}$ \\
\hline & & & $(0.032)$ & $(0.028)$ & $(0.030)$ \\
\hline \multirow[t]{2}{*}{ Europe pair } & & & $0.508^{* * *}$ & $0.595^{* * *}$ & $0.442^{* * *}$ \\
\hline & & & $(0.089)$ & $(0.088)$ & $(0.090)$ \\
\hline \multirow[t]{2}{*}{ Global (US) } & & & & $0.262^{* *}$ & \\
\hline & & & & $(0.111)$ & \\
\hline \multirow[t]{2}{*}{ East Asia global (US) } & & & & 0.207 & \\
\hline & & & & $(0.273)$ & \\
\hline \multirow[t]{2}{*}{ Europe global (US) } & & & & $1.221^{* * *}$ & \\
\hline & & & & $(0.326)$ & \\
\hline \multirow[t]{2}{*}{ Global (US \& UK) } & & & & & $0.194^{* * *}$ \\
\hline & & & & & $(0.060)$ \\
\hline \multirow[t]{2}{*}{ East Asia global (US \& UK) } & & & & & $0.337^{*}$ \\
\hline & & & & & $(0.199)$ \\
\hline \multirow[t]{2}{*}{ Europe global (US \& UK) } & & & & & $1.017^{* * *}$ \\
\hline & & & & & $(0.218)$ \\
\hline Observations & 12,625 & 12,625 & 12,625 & 12,625 & 12,625 \\
\hline R-squared & 0.315 & 0.315 & 0.321 & 0.350 & 0.355 \\
\hline
\end{tabular}

GDP = gross domestic product, UK = United Kingdom, US = United States.

Note: All the variables except GDP and per capita GDP data are bilateral ones between country $i$ and country $j$. The dependent variable is real portfolio investment asset holdings deflated by the US consumer price index where country $i$ is a source country and country $j$ is a destination country. The logarithm is taken after adding 1 to include all the observations with value 0 and some negative numbers. The observations with too great a negative value are excluded as outliers. All other explanatory variables except the dummy variables are in logarithms. Robust standard errors of the estimated coefficients are reported in parentheses. Intercept and year dummy variables are included (not reported).

** and * indicate that the estimated coefficients are statistically significant at the $1 \%$ and $5 \%$ levels, respectively.

Source: Authors' calculations. 


\section{REGIONAL FINANCIAL COOPERATION AND DIVERSIFICATION OF FUNDING SOURCES}

In Sections II and III, we confirmed that there is a strong global bias in East Asia in financial transactions. While Europe's high level of intraregional transactions does not necessarily reflect an optimal degree of regional integration, the results point to the possibility that there might be some scope for East Asia to further strengthen regional integration.

In fact, there has been strong demand for further regional integration from East Asian policy makers rooted in the widespread dissatisfaction with the performance of the IMF during the devastating Asian financial crisis of 1997. In the aftermath, East Asian governments concluded that there was no credible lender of last resort for the subregion. While the IMF provided critical lastminute loans to countries in crisis such as Indonesia, the Republic of Korea, and Thailand, the conditions imposed by the IMF were viewed as unnecessarily harsh and hence counterproductive.

More specifically, many of the policies prescribed by the IMF that were intended to restore financial and economic stability were inappropriate. For example, although these countries had relatively sound fiscal positions, they were forced to cut government spending which deepened the economic slowdown. Furthermore, even though inflation was already low and falling, they were forced to adopt tighter monetary policies. Indeed, such policies were exactly the opposite of those pursued by advanced economies when they were affected by the global financial crisis in 2008.

As a result of their dissatisfaction with the IMF, Asian policy makers adopted two major initiatives to promote regional financial cooperation. The first was the Chiang Mai Initiative (CMI) which began as a series of bilateral swap arrangements among the ASEAN +3 members after a meeting in 2000 in Chiang Mai, Thailand. Realizing that managing short-term liquidity problems was the key to preventing future crises, these countries sought to secure liquidity during emergencies through a network of bilateral deals; ${ }^{14}$ however, it turned out that the bilateral swaps could not meet the demand in an emergency. When the global financial crisis broke out in 2008, Asian governments did not turn to the CMI. For example, the Republic of Korea and Singapore formed bilateral swap agreements with the US Federal Reserve, and Indonesia was assisted by a financial consortium led by the World Bank. Consequently, Asian governments recognized that a reserve pooling arrangement like the IMF was needed.

In 2009, ASEAN+3 members agreed to expand the size of the fund and more importantly to change the arrangement from bilateral to multilateral. Hence, the Chiang Mai Initiative Multilateralized (CMIM) replaced the CMI. The CMIM plan materialized in 2010, and the total reserve pool amounted to $\$ 120$ billion, to which Japan and the PRC contributed 32\% each, the Republic of Korea $16 \%$, and the ASEAN members the remaining $20 \%$. The CMIM was doubled in size to $\$ 240$ in 2012.

The CMIM has been criticized on the grounds that the size of the fund is not nearly big enough to assist the larger Asian economies. Furthermore, in reality no funds are kept in a central entity; each government has simply promised to provide funds during an emergency. Those contributions still remain in each national central bank in the form of local currency. When funds are needed, governments will swap local currency for US dollars and contribute to the pool. Another problem is

14 While what Japan proposed initially was an Asian Monetary Fund, a regional version of the IMF, the US strongly resisted the idea since they worried that it would undermine IMF leadership and provide overly loose liquidity. See Lipscy (2003). 
that only a limited amount can be provided without an IMF program. In other words, the IMF conditions must be satisfied in order for a country in crisis to fully receive funds from the CMIM. The IMF conditionality is required because an effective CMIM system of surveillance and conditionality is not yet in place; however, given the hostility toward the IMF, this requirement makes it difficult for members to utilize the CMIM. In a fundamental sense, imposing IMF conditionality defeats the whole purpose of the CMIM - a regional desire for a regional alternative to the IMF.

The second major initiative for regional financial cooperation is the Asian Bond Markets Initiative (ABMI) launched in 2003 by ASEAN+3 members to foster regional bond markets. One of the motivations for developing local currency bond markets came from the lesson learned in the Asian financial crisis in 1997. At that time, Asian countries faced the "dual mismatch" problem on their balance sheets, i.e. currency and maturity mismatches. The currency mismatch reflected the fact that while the region as a whole was running a savings surplus, the surplus was mainly invested in global financial centers, so when governments needed to borrow funds for domestic uses, they had to rely on sources outside of the region, and the liabilities were mostly denoted in US dollars. The maturity mismatch problem refers to the fact that Asian economies financed long-term investments through short-term borrowings. The dual mismatch problem is partly the result of overreliance on bank financing. The bank-oriented financial system encouraged local companies to depend heavily on short-term bank loans instead of long-term financing through bond markets.

There have been some successes under ABMI. These include establishing a group of experts on cross-border bond transactions and settlement issues in 2008, the Credit Guarantee Investment Mechanism in 2009, the Credit Guarantee Investment Facility in 2010, and the Asian Bond Market Forum in 2010. Local-currency-denominated bond markets in the region have grown both in size and in diversity of issuers. The value of outstanding ASEAN+3 (excluding Japan) local-currencydenominated bonds increased to $\$ 6.365$ trillion in 2012 from $\$ 1.099$ trillion in 2002; however, significant constraints stand in the way of the further development of regional bond markets. ${ }^{15}$ Some Asian currencies remain inconvertible, and Asian countries vary greatly in income and economic development. The region also lacks a common bond market infrastructure. More specifically, different legal and regulatory frameworks, information disclosure standards, bankruptcy procedures, clearance and settlement institutions, and credit rating agencies all impede the development of a regional bond market.

So far we have seen that progress in regional financial cooperation in East Asia has been slow. This brings up the fundamental question of what the region would gain from strengthening financial cooperation and integration, or, equivalently, what the region is losing from its limited financial cooperation and integration. A number of studies have investigated if limited intra-Asian integration of financial markets implies incomplete risk diversification. For example, Kim, Lee, and Shin (2008) found that, compared to Europe, Asia tends to have weak regional risk sharing arrangements and strong global risk sharing arrangements. We now examine the issue of the costs of Asia's limited intraregional financial integration from a different angle. While risk diversification is related to asset holdings, we focus on funding liabilities.

The fact that regional financial integration is limited implies that not only are Asian economies investing relatively less in the region but also that they borrow less from the region. The latter had particularly important implications during the global financial crisis because that crisis originated from

15 See, for example, He (2012). 
global financial centers outside Asia. If the global financial center pulls capital from a country that is heavily dependent on it for financing, the dependent country can suffer instability even though its fundamentals are relatively sound. For a country with limited diversification of funding sources, the impact of a global financial crisis could be especially severe because most external funding will dry up. On the other hand, if funding sources were more diversified, for example, if a country relied much more on other countries in the region, then other funding sources could be tapped during a global crisis. In this sense, if regional financial integration is strengthened, a country can be less vulnerable to crises, especially to crises originating in the global markets.

In order to investigate this possibility, we followed the approach adopted by Eichengreen and Gupta (2013). They proposed an innovative approach to figure out which countries were more likely to be hit by the US Federal Reserve's QE tapering. In May 2013, Federal Reserve Chairman Ben Bernanke mentioned the possibility of tapering which triggered a sharp depreciation in the exchange rates of many emerging economies widely known as QE taper tantrum. To understand why some countries were hit harder than others, Eichengreen and Gupta investigated what factors were responsible for the negative impact of the QE tapering talk.

The basic regression equation they estimated is as follows:

$$
E R D_{i}=X_{i} \beta+\epsilon_{i}
$$

where $E R D_{i}$ is exchange rate depreciation experienced by country $i$ between the end of April and the end of August 2013, and $X_{i}$ is a vector of country-specific factors for country $i$ that were expected to be responsible for exchange rate depreciation. The factors they considered were (i) deterioration in current account deficit and real exchange rate appreciation, (ii) the size of the financial market, and (iii) other variables related to economic fundamentals.

They found that countries that allowed the real exchange rate to appreciate during a QE period and subsequently experienced deterioration of their current accounts were hit more severely. They also found that there was little evidence that stronger macroeconomic fundamentals were helpful in stabilizing the exchange rate. Instead they found that the size of the financial markets-proxies for the degree of liquidity of financial markets - mattered. Following the same approach, Park, Ramayandi, and Shin (2014) found results quite consistent with Eichengreen and Gupta's; however, their results differed in the following important dimensions. First, when Park, Ramayandi, and Shin separated out actual capital flows from financial market liquidity, only capital flows had a significant effect; and second, domestic credit expansion, a new variable introduced, had a significant effect on depreciation.

Here we add another important factor representing the diversification of external liabilities and test whether countries with more diversified holdings of external liabilities were less vulnerable to taper tantrum. In Table 4, we report the regression results when we keep the explanatory variables that were found to be statistically significant by Park, Ramayandi, and Shin (2014) and add various measures of the diversification of liabilities. ${ }^{16}$ For each economy, we calculate the shares of liabilities financed from all partner economies and use the standard deviation of the shares as a proxy for the diversification of liabilities. In columns 1-4, we report the regression results when diversification is measured on the basis of total portfolio securities, equity securities, long-term debt securities, and short-term debt securities in 2012, respectively.

16 We did not include inflation and the exchange rate regime as explanatory variables, but the results do not change qualitatively when we add them. 
We found that all the coefficients of the diversification of liabilities were negative, indicating that economies with more diversified holdings of liabilities experienced less depreciation in their exchange rates. In particular, the coefficient of the diversification of short-term debt liabilities was negative and statistically significant regardless of the specification. The only exception is the result in column 7 where all other explanatory variables are simultaneously included; however, even in that case, the coefficient was still negative. Furthermore, if we include both linear and square terms, the coefficients of both are significant at $10 \%$, but this nonlinear relationship still implies that in the relevant range, the impact of diversification on exchange rate depreciation is negative.

The results in Table 4 are based solely on portfolio liabilities since CPIS data do not include bank lending. However, liabilities stemming from bank lending often play an important role in triggering financial crises. In emerging economies, crises are frequently characterized by twin crises, i.e. banking and currency crises occur simultaneously. ${ }^{17}$ Velasco (1987) showed that by intermediating foreign capital flows, the domestic banking sector can contribute to macroeconomic instability. Goldstein (2005) emphasized a vicious circle between banking crises and currency crises. Hence it is worthwhile to test the same diversification hypothesis on bank lending data.

We collected the bank lending data from the Bank for International Settlements (BIS). On the BIS web site, only aggregate bank lending data are reported; bilateral bank lending data are not publicly available, and only a limited number of central banks authorize the BIS to make their data available on request. In Asia, Hong Kong, China; Taipei,China; India; Indonesia; Japan; and the Republic of Korea are included as reporting economies. In total, there are 36; the list is shown in Appendix Table A.2. The table shows that these economies report their bank lending to as many as 195 partners. Since we are interested not in asset holdings but in liability holdings, we can rearrange data from the perspective of the partners and convert the data into bilateral liabilities data. Then we can construct liability data for all the economies used in the regression results in Table 4.

The limitation is that the bilateral liabilities do not cover all the liabilities of an economy but only liabilities owed to the 36 reporting; however, since they cover most major economies, the diversification calculated on the basis of the 36 reporting can be a good proxy for true diversification based on all source economies. Therefore, for each one we calculate the shares of bank lending borrowed from all those reporting and use the standard deviation of the shares as a proxy for the degree of diversification in bank lending.

In Table 5, the regression results based on the bank lending data are reported. In general, we found that countries with more diversified sources of bank lending were less vulnerable to QE tapering. When we added both the linear and square terms of bank lending diversification, we found that the coefficients of both terms were statistically significant at the $5 \%$ level except in column 5 where all the explanatory variables are included..$^{18}$ The nonlinear relationship again implies that in the relevant range, the impact of diversification on exchange rate depreciation is negative and hence economies with more diversified bank lending were less affected by QE tapering talk.

17 This characteristic of twin crises is heavily emphasized, for example, by Kaminsky and Reinhart (1999).

18 The coefficient of the square term in column 2 is significant at the $10 \%$ level. 


\section{Table 4: Diversity of Portfolio Liabilities and Factors Associated with Exchange Rate Depreciation, April-August 2013}

\begin{tabular}{|c|c|c|c|c|c|c|c|c|}
\hline \multirow[b]{2}{*}{ Dependent Variable } & \multicolumn{8}{|c|}{ Percent Change in Nominal Exchange Rate } \\
\hline & [1] & [2] & [3] & [4] & [5] & [6] & [7] & [8] \\
\hline $\begin{array}{l}\text { Increase in current } \\
\text { account deficit }\end{array}$ & & & & & $\begin{array}{l}0.261^{* * *} \\
(0.059)\end{array}$ & $\begin{array}{l}0.248^{* * *} \\
(0.056)\end{array}$ & $\begin{array}{l}0.208^{* * *} \\
(0.063)\end{array}$ & $\begin{array}{l}0.215^{* * *} \\
(0.062)\end{array}$ \\
\hline $\begin{array}{l}\text { Average annual } \\
\text { percent change in } \\
\text { real exchange } \\
\text { rate, } 2009-2012\end{array}$ & & & & & $\begin{array}{l}-51.929^{* * *} \\
(13.105)\end{array}$ & $\begin{array}{l}-46.764^{* * *} \\
(12.528)\end{array}$ & $\begin{array}{l}-55.392^{* * *} \\
(17.372)\end{array}$ & $\begin{array}{c}-52.179^{* * *} \\
(16.987)\end{array}$ \\
\hline $\begin{array}{l}\text { Increase in credit to } \\
\text { GDP ratio, 2009- } \\
2012\end{array}$ & & & & & & $\begin{array}{l}0.097^{* *} \\
(0.042)\end{array}$ & $\begin{array}{c}0.058 \\
(0.048)\end{array}$ & $\begin{array}{c}0.096^{*} \\
(0.052)\end{array}$ \\
\hline $\begin{array}{l}\text { Capital flows during } \\
\text { QE1 }\end{array}$ & & & & & & & $\begin{array}{c}16.377 \\
(10.305)\end{array}$ & $\begin{array}{c}9.571 \\
(10.774)\end{array}$ \\
\hline $\begin{array}{l}\text { Diversity in } \\
\text { aggregate } \\
\text { portfolio } 2012\end{array}$ & $\begin{array}{l}-3.356 \\
(5.224)\end{array}$ & & & & & & & \\
\hline $\begin{array}{l}\text { Diversity in } \\
\text { equity } 2012\end{array}$ & & $\begin{array}{l}-3.947 \\
(3.695)\end{array}$ & & & & & & \\
\hline $\begin{array}{l}\text { Diversity in long- } \\
\text { term debt } 2012\end{array}$ & & & $\begin{array}{l}-6.673 \\
(4.272)\end{array}$ & & & & & \\
\hline $\begin{array}{l}\text { Diversity in short- } \\
\text { term debt } 2012\end{array}$ & & & & $\begin{array}{l}-14.747^{* * *} \\
(4.922)\end{array}$ & $\begin{array}{l}-8.776^{* *} \\
(3.707)\end{array}$ & $\begin{array}{l}-7.378^{* *} \\
(3.557)\end{array}$ & $\begin{array}{l}-6.653 \\
(5.091)\end{array}$ & $\begin{array}{l}-35.560^{*} \\
(17.574)\end{array}$ \\
\hline 2012 & & & & & & & & $\begin{array}{r}44.449^{*} \\
(25.930)\end{array}$ \\
\hline R-squared & 0.007 & 0.020 & 0.040 & 0.160 & 0.576 & 0.632 & 0.680 & 0.707 \\
\hline Observations & 62 & 59 & 60 & 49 & 49 & 48 & 39 & 39 \\
\hline
\end{tabular}

GDP = gross domestic product, QE1 = first period of quantitative easing (first quarter of 2009 to the third quarter of 2010).

Note: The dependent variable is exchange rate depreciation experienced by the developing country between the end of April and the end of August 2013. See Park, Ramayandi, and Shin (2014) for the developing countries included. An increase in nominal and real exchange rates represents depreciation. Numbers in parentheses are standard errors. ${ }^{* * *},{ }^{* *}$, and ${ }^{*}$ denote the significance levels of $1 \%, 5 \%$ and $10 \%$, respectively. Source: Authors' calculations. 


\section{Table 5: Diversity of Bank Lending Liabilities and Factors Associated with Exchange Rate Depreciation, April-August 2013}

\begin{tabular}{|c|c|c|c|c|c|}
\hline \multirow[b]{2}{*}{ Dependent Variable } & \multicolumn{5}{|c|}{ Percent Change in Nominal Exchange Rate } \\
\hline & {$[1]$} & [2] & [3] & {$[4]$} & {$[5]$} \\
\hline Increase in current account deficit & & & $\begin{array}{l}0.253^{* * *} \\
(0.057)\end{array}$ & $\begin{array}{l}0.234^{* * *} \\
(0.054)\end{array}$ & $\begin{array}{l}0.196^{* * *} \\
(0.061)\end{array}$ \\
\hline $\begin{array}{l}\text { Average annual percent change in } \\
\text { real exchange rate, 2009-2012 }\end{array}$ & & & $\begin{array}{l}-65.099^{* * *} \\
(10.568)\end{array}$ & $\begin{array}{l}-60.804^{* * *} \\
(10.025)\end{array}$ & $\begin{array}{l}-67.881^{* * *} \\
(12.773)\end{array}$ \\
\hline $\begin{array}{l}\text { Increase in credit to GDP ratio, } \\
2009-2012\end{array}$ & & & & $\begin{array}{l}0.112^{* * *} \\
(0.038)\end{array}$ & $\begin{array}{c}0.076^{*} \\
(0.045)\end{array}$ \\
\hline Capital flows during QE1 & & & & & $\begin{array}{r}15.320 \\
(10.571)\end{array}$ \\
\hline Diversity in bank lending 2012 & $\begin{array}{l}-3.024 \\
(4.895)\end{array}$ & $\begin{array}{l}-41.629^{* *} \\
(20.415)\end{array}$ & $\begin{array}{l}-30.225^{* *} \\
(13.805)\end{array}$ & $\begin{array}{l}-31.301^{* *} \\
(12.981)\end{array}$ & $\begin{array}{l}-20.017 \\
(16.481)\end{array}$ \\
\hline Square of diversity in bank lending 2012 & & $\begin{array}{l}55.548^{*} \\
(28.556)\end{array}$ & $\begin{array}{l}43.345^{* *} \\
(19.280)\end{array}$ & $\begin{array}{l}43.743^{* *} \\
(18.110)\end{array}$ & $\begin{array}{c}31.764 \\
(21.927)\end{array}$ \\
\hline R-squared & 0.006 & 0.066 & 0.591 & 0.654 & 0.693 \\
\hline Observations & 62 & 62 & 62 & 60 & 48 \\
\hline
\end{tabular}

GDP = gross domestic product, QE1 = first period of quantitative easing (first quarter of 2009 to the third quarter of 2010 ).

Note: The dependent variable is exchange rate depreciation experienced by the developing country between the end of April and the end of August 2013. An increase in nominal and real exchange rates represents depreciation. Numbers in parentheses are standard errors. ${ }^{* *},{ }^{* *}$, and * denote the significance levels of $1 \%, 5 \%$ and $10 \%$, respectively.

Source: Authors' calculations.

We also showed the relation between exchange rate depreciation and the five measures of diversification in liabilities: total portfolio (Figure 3.a), equity securities (Figure 3.b), long-term debt securities (Figure 3.c), short-term debt securities (Figure 3.d), and bank lending (Figure 3.e). These figures and the results in Tables 4 and 5 suggest that diversification in liabilities can limit the adverse impact of global financial shocks on financial stability. Therefore, to the extent that regional financial integration in East Asia promotes diversification of funding sources, our findings suggest another potential benefit of intraregional integration. 
Figure 3: Diversity of Liabilities and Exchange Rate Depreciation, 2012

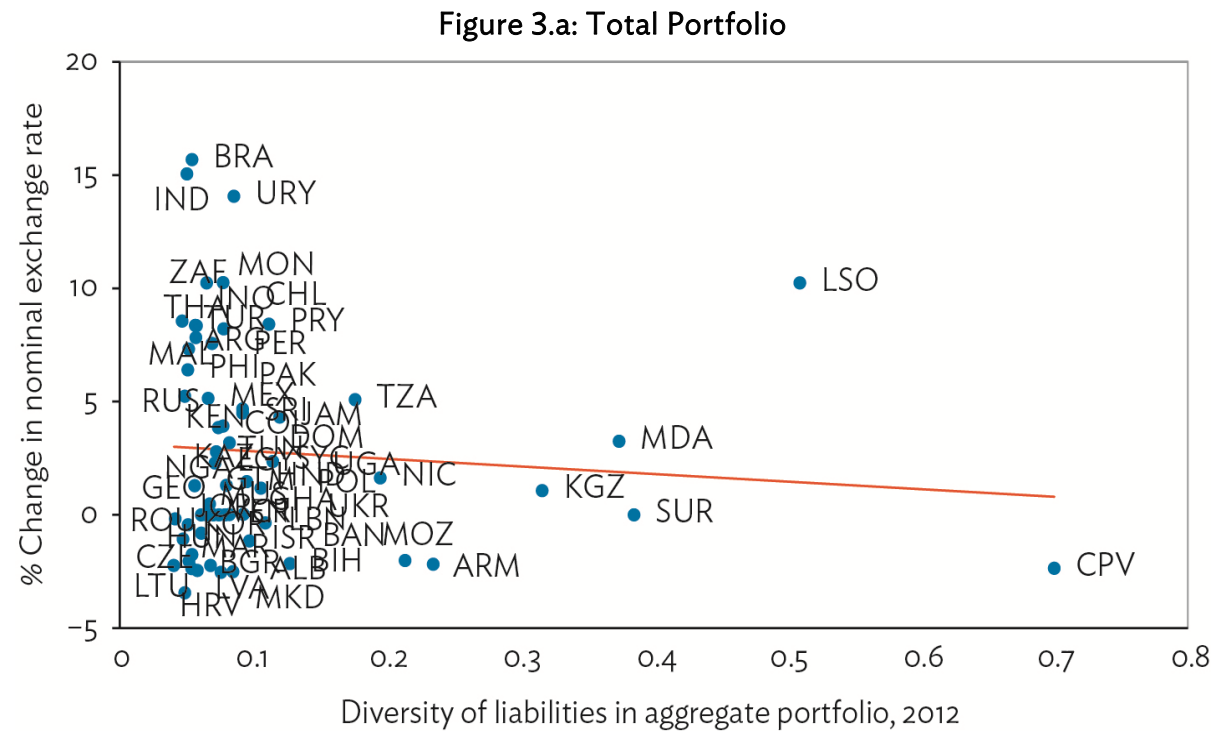

Figure 3.b: Equity Securities

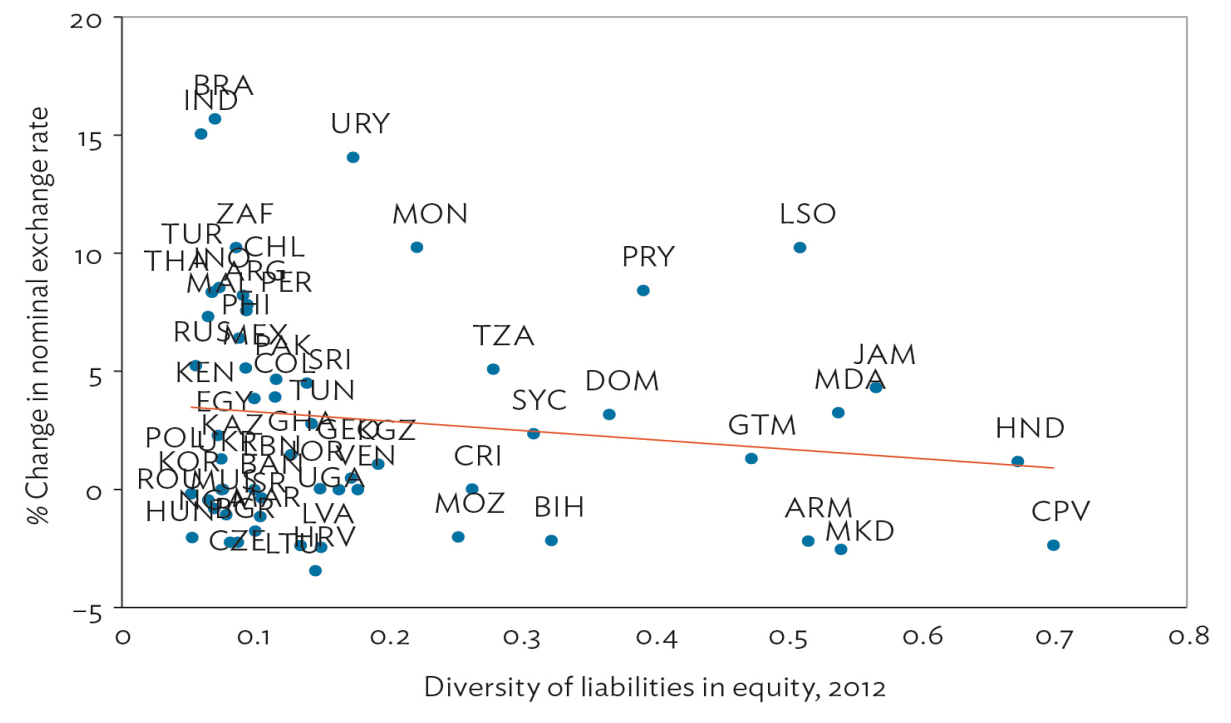

continued on next page 
Figure 3 continued

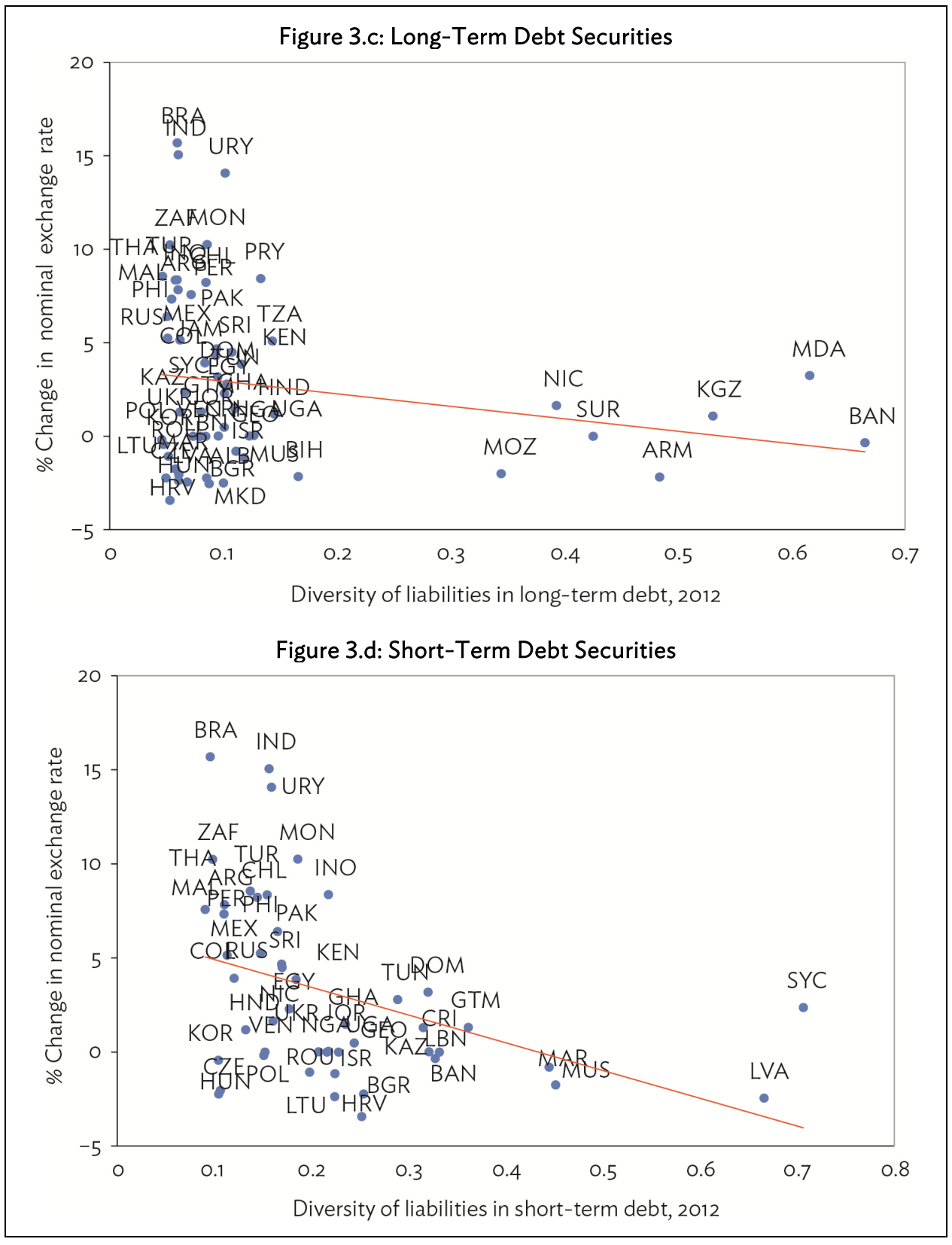

continued on next page 


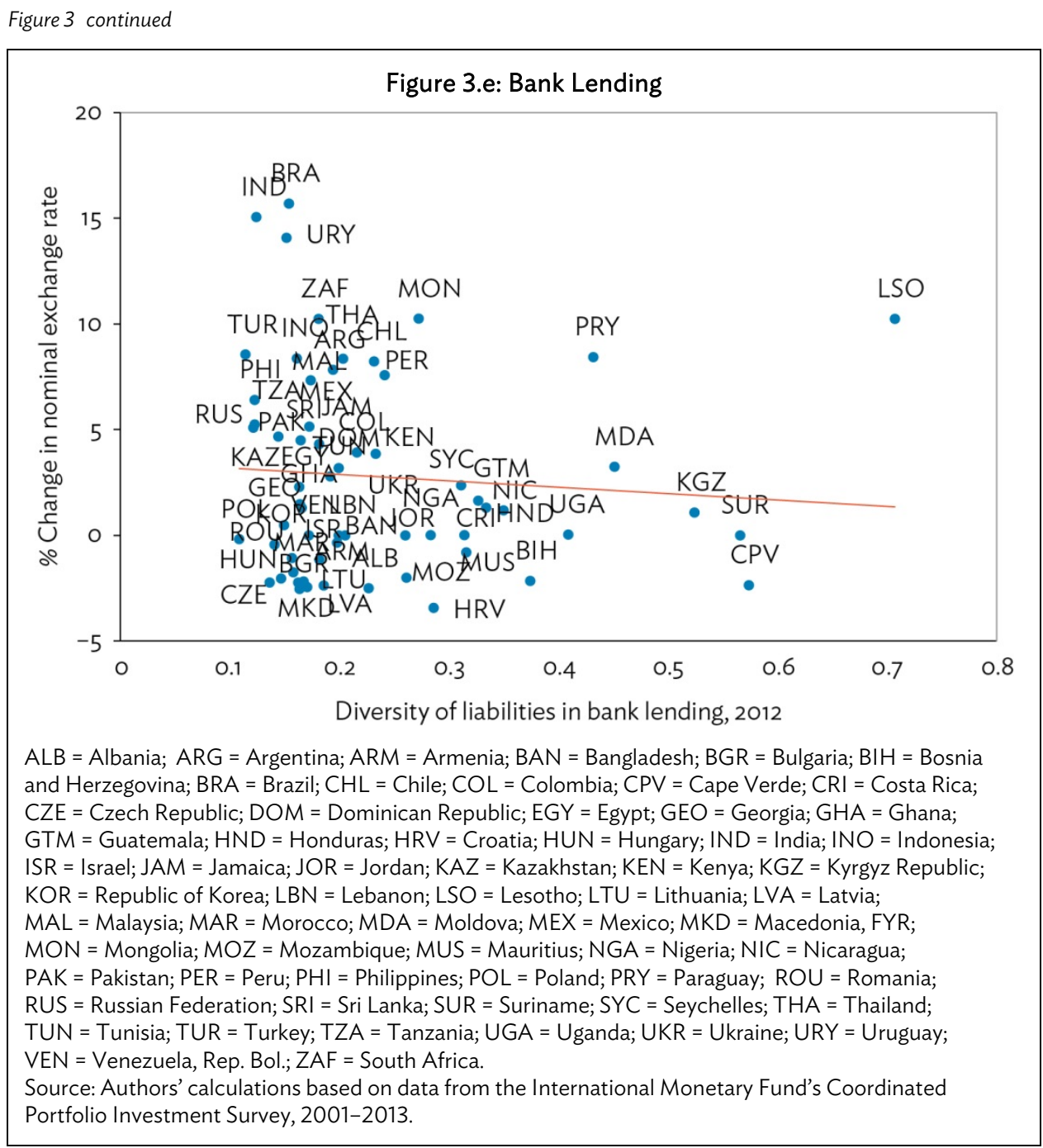

\section{CONCLUSIONS}

In this paper, we analyze the extent to which financial integration in East Asia has evolved over time. While most previous studies looked primarily at financial integration in terms of asset holdings, we particularly examined financial integration in terms of liability holdings. In general, the evidence confirms the conventional wisdom that East Asian economies are much more integrated globally than regionally. In terms of asset holdings, however, global integration has been decreasing and regional integration has been increasing. In fact, since 2007, regional integration has exceeded global integration. This trend is especially evident in long-term debt and short-term debt. In equity, however, global integration still exceeds regional integration. In Europe, the extent of regional integration is much greater than that of global integration, and the share of both has remained stable over time.

If we measure financial integration based on liability holdings, the picture is somewhat different. In both East Asia and Europe, the share of global integration and regional integration has not changed much over time. For total portfolio liabilities, the degree of global integration is higher than that of regional integration in East Asia. The reason that global integration exceeds regional integration 
is mainly due to equity liabilities. For long-term debt and short-term debt liabilities, the degree of global integration is actually lower than that of regional integration. In contrast, in Europe the degree of regional integration is much higher than that of global integration for all three types of portfolio investment. By and large, an econometric analysis based on the financial gravity model supports the general patterns that emerge from the descriptive analysis. In particular, our econometric results reconfirm that Europe is more financially integrated regionally than East Asia.

While some studies examine the benefits of diversifying asset holdings, we instead considered potential benefits from diversifying liability holdings. To do so, we investigated the effect of such diversification on exchange rate depreciation during the QE taper tantrum of 2013 and found that diversification of external funding sources helped to limit depreciation. Our finding thus suggests that diversification in external liability holdings can mitigate financial instability due to shocks from global financial markets which in turn implies that an excessive degree of global integration can be undesirable. Deeper regional financial integration can reduce dependence on global financial markets for funding and thus vulnerability to global shocks. Therefore, our evidence provides some indirect support for the efforts of Asian governments to further deepen regional financial integration. 


\section{APPENDIX}

Table A.1: Definitions of Variables and Data Sources

\begin{tabular}{|c|c|c|}
\hline Variables & Description and Construction & Data Source \\
\hline Portfolio assets and liabilities & $\begin{array}{l}\text { Sum of assets (liabilities) in foreign } \\
\text { holdings of direct investment, equity, } \\
\text { debt securities, and debt instruments }\end{array}$ & $\begin{array}{l}\text { Coordinated Portfolio Investment } \\
\text { Survey, International Monetary Fund's } \\
\text { (IMF) International Financial Statistics } \\
\text { (IFS) database (2001-2013) }\end{array}$ \\
\hline $\begin{array}{l}\text { Gross domestic product (GDP) } \\
\text { (constant } 2005 \text { US } \$ \text { ) }\end{array}$ & GDP in constant 2005 US\$. & $\begin{array}{l}\text { World Bank's World Development } \\
\text { Indicators }\end{array}$ \\
\hline GDP per capita (constant 2005 US\$) & $\begin{array}{l}\text { GDP divided by mid-year population. } \\
\text { Data are in constant } 2005 \text { US\$ }\end{array}$ & World Development Indicators \\
\hline GDP (current US\$) & GDP in current US\$ & World Development Indicators \\
\hline Inflation (consumer price index $[\mathrm{CPI}]$ ) & $\begin{array}{l}\text { Inflation, CPI for all urban consumers: } \\
\text { All items (annual \%) }\end{array}$ & $\begin{array}{l}\text { US Department of Labor: Bureau of } \\
\text { Labor Statistics }\end{array}$ \\
\hline Exports/Imports & Export f.o.b./Imports f.o.b. & $\begin{array}{l}\text { IMF's Direction of Trade database } \\
(2001-2013)\end{array}$ \\
\hline Country rating & Overall Risk Rating Score & DataStream \\
\hline $\begin{array}{l}\text { Percent change in nominal exchange } \\
\text { rate }\end{array}$ & $\begin{array}{l}\text { Log difference in nominal exchange } \\
\text { rate (national currency per US\$) } \\
\text { between April-August } 2013\end{array}$ & IFS database \\
\hline $\begin{array}{l}\text { Increase in current account deficit, } \\
2010-2012\end{array}$ & $\begin{array}{l}\text { Difference in current account deficit } \\
\text { between 2010-2012 }\end{array}$ & World Development Indicators \\
\hline $\begin{array}{l}\text { Average annual \% change in real } \\
\text { exchange rate } 2009-2012\end{array}$ & $\begin{array}{l}\text { [Log nominal exchange rate } \\
2012 \mathrm{M} 12 \text { (IFS) }{ }^{*} \mathrm{CPI} \text { of US } 2012 \mathrm{M} 12 \\
\text { (IFS)/CPI of each country } 2012 \\
\mathrm{M} 12 \text { (IFS) - Log nominal exchange } \\
\text { rate } 2009 \mathrm{M} 1 \text { (IFS) }{ }^{*} \mathrm{CPI} \text { of US } \\
2009 \mathrm{M} 1(\mathrm{IFS}) / \mathrm{CPI} \text { of each country } \\
2009 \mathrm{M} 1(\mathrm{IFS})] / 3\end{array}$ & IFS database \\
\hline Gross capital inflows & $\begin{array}{l}\text { Sum of changes in foreign holdings of } \\
\text { direct investment, equity, debt } \\
\text { securities, and debt instruments }\end{array}$ & IFS database \\
\hline Increase in credit to GDP 2009-2012 & $\begin{array}{l}\text { Increase in domestic credit to private } \\
\text { sector (\% of GDP) between 2009- } \\
2012\end{array}$ & World Development Indicators \\
\hline
\end{tabular}


Table A.2: List of Sources in the Bank Loan Data

\begin{tabular}{|c|c|c|}
\hline & Source & No. of Partners \\
\hline 1 & Australia & 169 \\
\hline 2 & Austria & 176 \\
\hline 3 & Belgium & 190 \\
\hline 4 & Bermuda & 58 \\
\hline 5 & Brazil & 55 \\
\hline 6 & Canada & 177 \\
\hline 7 & Cayman Islands & 176 \\
\hline 8 & Chile & 66 \\
\hline 9 & Cyprus & 143 \\
\hline 10 & Denmark & 186 \\
\hline 11 & Finland & 154 \\
\hline 12 & France & 191 \\
\hline 13 & Germany & 187 \\
\hline 14 & Greece & 38 \\
\hline 15 & Hong Kong, China & 141 \\
\hline 16 & India & 188 \\
\hline 17 & Indonesia & 61 \\
\hline 18 & Ireland & 176 \\
\hline 19 & Italy & 175 \\
\hline 20 & Japan & 117 \\
\hline 21 & Republic of Korea & 178 \\
\hline 22 & Luxembourg & 186 \\
\hline 23 & Macau, China & 84 \\
\hline 24 & Malaysia & 107 \\
\hline 25 & Mexico & 63 \\
\hline 26 & Netherlands & 185 \\
\hline 27 & Panama & 105 \\
\hline 28 & Portugal & 143 \\
\hline 29 & South Africa & 119 \\
\hline 30 & Spain & 175 \\
\hline 31 & Sweden & 167 \\
\hline 32 & Switzerland & 195 \\
\hline 33 & Taipei,China & 182 \\
\hline 34 & Turkey & 131 \\
\hline 35 & United Kingdom & 193 \\
\hline 36 & United States & 123 \\
\hline
\end{tabular}

Source: Bank for International Settlements. 


\section{REFERENCES}

Eichengreen, B. and P. Gupta. 2013. Tapering Talk: The Impact of Expectations of Reduced Federal Reserve Security Purchases on Emerging Markets. World Bank Policy Research Working Paper Series. No. 6754. Washington, DC: World Bank

Goldstein, I. 2005. Strategic Complementarities and the Twin Crises. The Economic Journal. 115. pp. 368-90.

Gourinchas, P.-O. and O. Jeanne. 2006. The Elusive Gains from International Financial Integration. Review of Economic Studies. 73 (3). pp. 715-41.

He, F. 2012. ABMI and Financial Cooperation in East Asia. Handout in Japan-People's Republic of China-Republic of Korea (A3) Conference on Monetary and Financial Cooperation in the Region. Tokyo. 24 May.

Kaminsky, G. L. and C. M. Reinhart. 1999. The Twin Crises: The Causes of Banking and Balance of Payments Problems. American Economic Review. 89 (3). pp. 473-500.

Kim, S., J.-W. Lee, and K. Shin. 2008. Regional and Global Financial Integration in East Asia. In B. Eichengreen, C. Wyplosz, and Y. Park, eds. China, Asia and the New World Economy. Oxford: Oxford University Press.

Kose, A., E. Prasad, K. Rogoff, and S.-J. Wei. 2009. Financial Globalization: A Reappraisal. International Monetary Fund Staff Papers. 56 (1). pp. 8-62.

Lane, P. R. and G. M. Milesi-Ferretti. 2003. International Financial Integration. International Monetary Fund Staff Papers. 50 (Special Issue). pp. 82-113.

Lee, J.-W. and C.-Y. Park. 2011. Financial Integration in Emerging Asia: Challenges and Prospects. Asian Economic Policy Review. 6 (2). pp. 176-98.

Lee, J.-W. and K. Shin. 2012. Welfare Implications of International Financial Integration. Japan and the World Economy. 24 (4). pp. 235-45.

Lipscy, P. Y. 2003. Japan's Asian Monetary Fund Proposal. Stanford Journal of East Asian Affairs. 3 (1). pp. 93-104.

Lucas, R. E. 1990. Why doesn't Capital Flow from Rich to Poor Countries? American Economic Review. 80. pp. 92-96.

Park, D., A. Ramayandi, and K. Shin. 2014. Capital Flows during Quantitative Easing and Aftermath: Experiences of Asian Countries. ADB Economics Working Paper Series. No. 409. Manila: Asian Development Bank.

Portes, R. and H. Rey. 2005. The Determinants of Cross Border Equity Flows. Journal of International Economics. 65 (2). pp. 269-96. 
Rose, A. and M. Spiegel. 2004. A Gravity Model of International Lending: Trade, Default and Credit. International Monetary Fund Staff Papers. 51. pp. 50-63.

Sohn, C.-H. and K. Shin. 2006. Trade and Financial Integration in East Asia: Effects on Co-movements. World Economy. 29 (12). pp. 1649-69.

Velasco, A. 1987. Financial and Balance of Payments Crises. Journal of Development Economics. 27 (1-2). pp. 263-83. 


\section{Financial Integration in Asset and Liability Holdings in East Asia}

Findings from the paper generally support the conventional wisdom that East Asian countries are more financially integrated with global financial centers than they are with each other. This is confirmed by econometric analysis based on financial gravity equations. Results of additional econometric analysis indicate that the diversification of liability holdings can mitigate financial instability due to global financial shocks. This suggests that a possible indirect benefit of regional financial integration is reduced vulnerability to such shocks.

\section{About the Asian Development Bank}

ADB's vision is an Asia and Pacific region free of poverty. Its mission is to help its developing member countries reduce poverty and improve the quality of life of their people. Despite the region's many successes, it remains home to the majority of the world's poor. ADB is committed to reducing poverty through inclusive economic growth, environmentally sustainable growth, and regional integration.

Based in Manila, ADB is owned by 67 members, including 48 from the region. Its main instruments for helping its developing member countries are policy dialogue, loans, equity investments, guarantees, grants, and technical assistance. 